\title{
How Birds Combat Ectoparasites
}

\author{
Dale H. Clayton*, ${ }^{, 1}$, Jennifer A. H. Koop ${ }^{1}$, Christopher W. Harbison ${ }^{1,2}$, Brett R. Moyer ${ }^{1,3}$ and \\ Sarah E. Bush ${ }^{1,4}$
}

${ }^{I}$ Department of Biology, University of Utah, Salt Lake City, UT 84112, USA; ${ }^{2}$ Current address: Biology Department, Siena College, Loudonville, NY, 12211, USA; ${ }^{3}$ Current address: Providence Day School, Charlotte, NC, 28270, USA; ${ }^{4}$ Natural History Museum and Biodiversity Research Center, University of Kansas, Lawrence, Kansas 66045, USA

\begin{abstract}
Birds are plagued by an impressive diversity of ectoparasites, ranging from feather-feeding lice, to featherdegrading bacteria. Many of these ectoparasites have severe negative effects on host fitness. It is therefore not surprising that selection on birds has favored a variety of possible adaptations for dealing with ectoparasites. The functional significance of some of these defenses has been well documented. Others have barely been studied, much less tested rigorously. In this article we review the evidence - or lack thereof - for many of the purported mechanisms birds have for dealing with ectoparasites. We concentrate on features of the plumage and its components, as well as anti-parasite behaviors. In some cases, we present original data from our own recent work. We make recommendations for future studies that could improve our understanding of this poorly known aspect of avian biology.
\end{abstract}

Keywords: Grooming, preening, dusting, sunning, molt, oil, anting, fumigation.

\section{INTRODUCTION}

As a class, birds (Aves) are the most thoroughly studied group of organisms on earth. Nevertheless, the adaptive function of many intriguing features of avian morphology, physiology, and behavior are still uncertain. Some of these features are thought to play a role in defense against harmful ectoparasites. Examples include the pectinate middle claw of many birds, the strange odors of some birds, and the odd "maintenance" behaviors, such as sunning, anting or dusting, performed by many birds. In this article we review the ways in which birds are thought to combat ectoparasites. We pay particular attention to possible anti-parasite features of the plumage itself, as well as various forms of anti-parasite behavior. Although the immune system also plays an important role in defense against some ectoparasites, such as bloodfeeding mites [1], we do not cover immune defenses in this review. Instead, we refer readers to other papers in this volume, and recent reviews of immunology published elsewhere, e.g. [2] and [3].

In the classic work Fleas, Flukes and Cuckoos, Rothschild and Clay [4] catalogued the incredibly rich diversity of parasitic organisms inhabiting birds, including groups as different as viruses, fungi, bacteria, protozoa, worms and arthropods. The major groups with ectoparasitic forms are as follows:

1) Insects: Four orders, including lice (Phthiraptera), fleas (Siphonaptera), true bugs (Hemiptera), and flies (Diptera) [5].

*Address correspondence to this author at the Department of Biology, University of Utah, Salt Lake City, UT 84112, USA; Tel: 801-581-6482;

Fax: 801-581-4668; E-mail: clayton@biology.utah.edu
2) Mites and ticks (Acari): many families [6-9].

3) Leeches: four families [10].

4) Fungi: keratinophilic and cellulose decomposing forms [11].

5) Bacteria: several unrelated groups that decompose feathers [12].

Relatively little was known about the impact of ectoparasites on non-game wild birds until about 25 years ago, when ornithologists began to take a strong interest in parasites. One catalyst was Hamilton and Zuk's influential 1982 [13] paper arguing that the elaborate visual and acoustic displays of many birds evolved as a result of parasite-mediated sexual selection. Since then, dozens of papers testing the impact of parasites on wild birds have been published. For reviews, including the topic of sexual selection, which we will not cover here, see [3, 14-21].

These studies confirm that many ectoparasites are potent agents of selection on birds, affecting both the survival and reproductive components of avian fitness. Not surprisingly, therefore, birds appear to have evolved a wide variety of defenses for controlling ectoparasites. Moyer and Clayton [22] provided a succinct review of defenses involving plumage as a barrier, and antiparasite behaviors of birds. Since their review, several dozen new papers have been published with information pertinent to these kinds of defenses. We review these papers below, and in some cases we report original data relevant to purported defenses.

We consider ectoparasites to include taxa that spend at least some of their life cycle in close association with the host, as opposed to more ephemeral "parasites", such as mosquitoes. We do not cover defenses aimed primarily at 
these ephemeral species, such as fly repelling behavior, defensive sleeping postures, microhabitat choice, territoriality, and "selfish herd" effects. For reviews of these topics see Lehane [23], Hart [24] and Weldon and Carroll [25].

We use parasite load in reference to any of the following more precise measures: richness (the number of species of parasites present); prevalence (the fraction of parasitized individuals in a host population); intensity (the number of individual parasites in an infested host); abundance (the number of individual parasites in a host, regardless of infestation). Hence, mean intensity is the average number of individual parasites across infested hosts in a population, and mean abundance is the average number of parasites across all host individuals, regardless of infestation. For further details see Bush et al. [26].

\section{PLUMAGE AS A BARRIER}

Most ectoparasites are in contact with the plumage, at least some of the time. Some ectoparasites, such as feather lice (Phthiraptera: suborder Ischnocera), are in contact with the plumage all of the time. Indeed, they even feed on feathers, which are digested with the aid of endosymbiotic bacteria [27]. It is therefore reasonable to expect that some chemical or mechanical features of the plumage may have evolved to deter ectoparasites, similar to the many features of foliage known to deter herbivorous insects [28]. Plumage related defenses might include feather molt, analogous to the abscission of plant leafs reducing infestations of leaf miners and other endophytic and sessile herbivorous insects (reviewed in Stiling et al. [29]).

\section{Feather Molt}

Conventional wisdom has it that feather molt helps reduce ectoparasite loads [5]. Indeed, molt presumably does help birds jettison immobile parasites, such as fungi and bacteria that live in the plumage. Burtt and Ichida [30] showed that the abundance of feather-degrading bacteria fluctuates seasonally, with the smallest infestations in the autumn, which is consistent with this hypothesis. But it remains unclear whether molt plays an important role in controlling more mobile parasites, such as mites and lice.

Records of lice on molted feathers suggest that molt may indeed reduce arthropod ectoparasite loads [31]. Post and Enders [32] attributed the low prevalence of lice on Sharptailed Sparrows (Ammodramus caudacutus), compared to Seaside Sparrows (A. maritimus), to the fact that the former molt twice a year, while the latter molt once a year. Several researchers have carried out longitudinal studies in which they documented an apparent reduction in ectoparasite load over the course of the host's molting period [33]. Baum [34] reported an $85 \%$ drop in the abundance of lice on molting Eurasian Blackbirds (Turdus merula). Markov [35] observed a decrease in the number of ectoparasites on European Starlings (Sturnus vulgaris) during the autumn, and argued that feather molt caused this decrease. However, Boyd [36] suggested that seasonal changes in climate were actually responsible for the autumn reductions. Changes in climatic factors particularly ambient humidity - are known to have a significant impact on ectoparasite abundance, at least in the case of lice $[22,37,38]$.
A recent longitudinal study of ectoparasite loads on House Finches (Carpodacus mexicanus) indicates that the relationship between molt and ectoparasite abundance can be complicated [39]. The results of this study show that the abundance of two species of feather mites (Strelkoviacarus sp. and Dermoglyphus sp.) increased, rather than decreased, during the molting season. The louse Menecanthus alaudae also increased during the molting season on male House Finches. The authors argued that the energetic cost of molt reduced the amount of energy birds could expend on activities such as preening, leading to an increase in ectoparasites. The authors also compared the ectoparasite loads of birds in various degrees of molt. Molting males had more feather mites than non-molting males, whereas the number of mites on molting vs. non-molting females did not differ significantly. In addition, the study showed that molting males had more lice than molting females. The authors suggest that these patterns are driven by the additional energetic costs associated with the possession of showy plumage in males.

Moyer et al. [40] conducted an experimental test of the impact of molt on ectoparasites. The authors manipulated photoperiod to trigger early molt in captive Rock Pigeons (Columba livia) infested with lice. They then tracked the abundance of lice on molting and non-molting (control) birds over the course of several weeks. Visual examination of lice on different body regions indicated that feather molt reduced louse abundance. However, body washing, a more robust method of quantifying lice [41], showed that molt did not, in fact, reduce the abundance of lice. Two factors caused visual examination to underestimate the number of lice on the molting birds. First, molt replaced worn feathers with new, lush plumage that obscured lice during visual examination. Second, lice sought refuge inside the sheaths of newly developing feathers, where they could not be seen. The illusion of reduced louse abundance documented by Moyer et al. [40] calls into question observational studies documenting apparent reductions in lice during molt. This may also be true for other ectoparasites.

A few studies of molt have used methods for quantifying ectoparasites that are more rigorous than visual examination. For example, Chandra et al. [42] fumigated Common Mynas (Acridotheres tristis), ruffled their plumage, and quantified the lice. McGroarty and Dobson [43] used body washing to determine the number of lice on House Sparrows (Passer domesticus). Both studies showed a reduction in louse abundance in late summer, coincident with the postnuptial molt of the host. However, experimental manipulations are still needed to establish molt as the cause of these decreases, rather than some third factor that covaries with both molt and ectoparasite reductions. One such factor could simply be transmission of lice from parent to offspring birds. Lice typically move in large numbers from parent birds to their offspring at the end of the breeding season, leading to a decrease in the abundance of lice on adult birds around the time of molt [44-47]. Dispersal of lice to juveniles could also explain why fewer newly deposited feather louse eggs are found on adult feathers near the end of the host's breeding season [48].

Host physiological constraints may give many ectoparasites time to circumvent molt, which tends to be a gradual process in most birds because thermal insulation and aerody- 
namic efficiency are both compromised in proportion to the number of missing feathers $[49,50]$. Energy is also required, of course, to create each new feather [51]. Feather quality can be inversely proportional to the rate of molt, further suggesting constraints on rapid molt [52]. If feathers are lost gradually, then it may be possible for ectoparasites to avoid feathers that will soon be molted. A survey of feather mite distributions on the flight feathers of molting passerines shows that mites can, in fact, avoid molting feathers [53]. Similarly, mites that live inside the quills of feathers (Syringophilidae) are known to abandon the old feathers in favor of new ones before the old ones molt $[54,55]$.

Two mechanisms have been proposed to explain how ectoparasites detect and avoid molting feathers [56]. The "vibration" hypothesis proposes that the cue used by the ectoparasites is the vibration caused by rocking of the old feather as it is pushed out of a follicle by the newly emerging feather. The "window" hypothesis proposes that ectoparasites on sequentially molting flight feathers can detect changes in movement or airflow caused by absence of the adjacent, molted feather. Pap et al. [57] addressed both hypotheses in a clever experiment. To test the window hypothesis they removed the sixth primary feather from nonmolting Barn Swallows (Hirundo rustica). To test the vibration hypothesis they cut part way through the shaft of the sixth primary feather of the opposite wing to simulate vibration in a molting feather. The simulated window did not cause mites to leave the adjacent (seventh) primary on the first wing, suggesting that the vibration hypothesis might be the correct explanation. Unfortunately, the authors did not report whether mites left the partially cut sixth primary on the opposite wing, nor did they report the number of mites on the fifth primary, which is one place the mites would be expected to move in response to vibration. The authors did note a decrease in the number of mites on the eighth primary, but the relevance of this observation is unclear. Interestingly, experimental birds with pulled or cut feathers had significantly fewer mites on the flight feathers than did control birds at the end of the experiment. The authors suggested that the mites may have moved from flight feathers onto body feathers to escape molt, but there were no data with which to test this hypothesis.

Jovani et al. [56] also evaluated the two hypotheses using mites on Barn Swallows. As in many birds, there is a time lag between molting of a primary feather, which creates a window, and hypothesized vibration in the adjacent feather before that feather also molts. Jovani et al. [56] found that mites stayed on feathers near the window for a long time, moving only when the feather was nearly ready to drop. As in the case of Pap et al.'s study [57] this observation suggests that vibration may be a more important cue than the appearance of a window. However, additional experimental manipulations of cues that ectoparasites could use to detect molt are needed for a more complete understanding of this question.

\section{Feather Toughness}

Feathers containing melanin-the pigment typically responsible for brown, gray or black colors [58] - are more resistant to mechanical abrasion than feathers without melanin $[59,60]$. This toughness makes melanin rich feathers more resistant to wear and tear, and may also deter featherfeeding ectoparasites. Two studies suggest that melanin can limit damage by feather feeding lice [61, 62]. Kose and colleagues [61] surveyed feather damage in Barn Swallow (Hirundo rustica) populations and found that the holes chewed by lice were significantly more likely to occur in the white (melanin-free) spots on the tail feathers, compared to black (melanin-rich) regions of the tail. The authors conducted a louse-preference trial in vitro and found that the lice preferred to be on white portions of the tail feathers. Unfortunately, recent evidence indicates that the louse genus studied by Kose et al. [61] is not the one that creates holes in the feathers, thus bringing into question the relevance of their experiment. Kose et al. [61] studied preferences of the louse Machaerilaemus malleus (synonym: Hirundoecus malleus), in the family Menoponidae, whose members often feed on blood and feathers [63]. The holes in Barn Swallow tail feathers appear to be caused by members of the genus Brueelia [64], in the family Philopteridae, whose members typically feed on feathers and dead skin. The experiments performed by Kose et al. [61] need to be repeated using Brueelia.

Experiments conducted by Bush et al. [65] indicate that melanin does not have an effect on feather-feeding lice from Rock Pigeons. The authors captured pigeons of different color morphs ranging from white to black. Feather-feeding lice (Columbicola columbae, and Campanulotes compar) were fed feathers from these birds in vitro. After two weeks, there was no significant difference in the amount of feather material consumed, nor in the survival of lice on feathers with different amounts of melanin. Additional experiments with $C$. columbae showed that there was no significant difference in reproduction of lice on white vs. black feathers, nor did the lice exhibit a preference for different colored feathers.

Melanized feathers may be more resistant to featherdegrading bacteria (FDB). Three studies have addressed this question by exposing Bacillus licheniformis, a common strain of FDB, to melanized and unmelanized feathers. Goldstein et al. [66] suggested that melanized feathers resisted degradation by FDB; however, this study was performed without adequate controls or replicates [67]. In contrast, Grande et al. [68] found that FDB actually degraded melanized feathers faster than unmelanized feathers; however, in this study feather degradation was scored visually, which may be problematic because color could bias human perception of degradation. In an attempt to remedy these shortcomings, Gunderson et al. [67] conducted an experiment where goose feathers were inoculated with $B$. licheniformis. They found that melanized feathers had lower bacterial densities, degraded more slowly, and had less degradation than unmelanized feathers, indicating that melanin does, in fact, deter at least one strain of FDB in vitro.

Many species of birds have melanic morphs, and the darker morphs typically live in more humid regions - a pattern known as Gloger's rule [69]. Burtt and Ichida [70] hypothesized that this pattern may be driven by FDB, which thrive in humid conditions. They compared the degradation rates of $B$. licheniformis isolated from darkly colored Song Sparrows (Melospiza melodia) from a humid region and more lightly colored Song Sparrows from an arid region. By growing 
these bacterial isolates on chicken feathers under "common garden" laboratory conditions, the authors showed that the bacteria from the humid region degraded feathers faster than bacteria from the arid region. Burtt and Ichida [70] suggested that Song Sparrows in humid regions (where bacteria do better) evolved more melanin because of increased pressure from the more detrimental strain of $B$. licheniformis.

In another study, Cristol et al. [71] inoculated the feathers of live birds with $B$. licheniformis to test the impact of sunning behavior on FDB. They noticed that darkly colored European Starlings (Sturnus vulgaris) had far less damage than more lightly colored Northern Cardinals (Cardinalis cardinalis). However, as the authors themselves point out, these data are only suggestive, since the experiments with starlings and cardinals were run at different temperatures, humidities, and for different lengths of time.

In summary, studies with B. licheniformis [70, 71] suggest that melanin may be an important defense against FDB. However, experiments manipulating bacteria in vivo on light and dark birds are needed for a more convincing test of this hypothesis, as well as to test the fitness consequences of FDB for birds [72]. Moreover, studies are needed to understand how melanin affects bacterial communities. Interactions between bacteria could alter how we interpret the role of melanin as a bacterial defense. Experiments done in vivo should, if possible, incorporate whole communities of FDB, not just $B$. licheniformis, which is often studied because it can be cultured in vitro. Work is also needed to elucidate the precise mechanism(s) by which melanins deter bacteria [67]. It is entirely possible that an antibacterial role of melanin could have more to do with its influence on the avian immune system [3] than it's influence on feather hardness (see other articles in this volume).

\section{FEATHER TOXINS}

Toxins in the plumage of some birds may help combat ectoparasites $[25,73]$. The best-known example is batrachotoxins in the feathers and skin of several species in the New Guinea passerine genera Pitohui and Ifrita [74, 75]. Batrachotoxins, which are also found in the skin of poison dart frogs, (Phyllobates spp.) are thought to play a role in deterring predators. Experimental evidence suggests that the toxins also deter ectoparasites [76-78]. Dumbacher [78] conducted a series of in vitro trials in which he exposed feather lice from a variety of bird species to feathers of Pitohui and other non-toxic birds. He found that lice avoid feeding or resting on Pitohui feathers when they are given a choice. Lice on Pitohui feathers also show higher mortality than lice on non-toxic feathers. Since batrachotoxin detrimentally affects a wide variety of invertebrates [78], it may deter other ectoparasites in addition to lice. Interestingly, a survey of $30 \mathrm{New}$ Guinea passerine genera showed that Pitohuis had the lowest tick loads [79]. Another study showed that the family Pachycephalidae, which includes the genus Pitohui, has comparatively few arthropod-vectored haematozoan parasites [80].

\section{Odorous Feathers}

At least 80 genera of birds in 17 orders produce odors that humans can readily detect [81]. It is possible that one adaptive function of such odors is to combat ectoparasites.
This hypothesis has been tested most thoroughly in Crested Auklets (Aethia cristatella) (Fig. 1), which emit a pungent citrus-like odor that humans can detect at a considerable distance from breeding colonies [82]. Douglas et al. [83] identified the odor constituents as a series of short-chained, saturated and monounsaturated aldehydes, which are corrosive irritants that are volatile and reactive. The authors suggested that the citrus odor might repel ectoparasites since two of the major constituents, hexanal and octanal, are known arthropod repellents.

Douglas et al. [84] tested the effect of synthetic versions of auklet odorant compounds on two genera of auklet lice (Austomenopon sp. and Quadraceps sp.). Lice exposed to $1 \mu \mathrm{l}$ of either octanal or Z-4-decanal became moribund in seconds. In contrast, when Douglas et al. [85] exposed Rock Pigeon lice (Columbicola columbae and Campanulotes compar) to fresh auklet feathers placed in covered petri dishes with lice, or to fresh auklet carcasses sealed in beakers with lice, there was no effect on parasite survival. Douglas et al. [85] also compared the relative abundance of lice on Crested Auklets to lice on Least Auklets (A. pusilla), which do not emit a noticeable odor (the birds were from the same mixed breeding colony). They found that Crested Auklets actually had significantly more lice than Least Auklets, even after controlling for a difference in host body size.

Douglas et al. [84] also tested the effect of synthetic versions of auklet odorant compounds on two species of ticks. Laboratory reared ticks (Amblyomma americanum) were exposed to octanal on an artificial host consisting of filter paper attached to a heated, rotating drum. Ticks detached

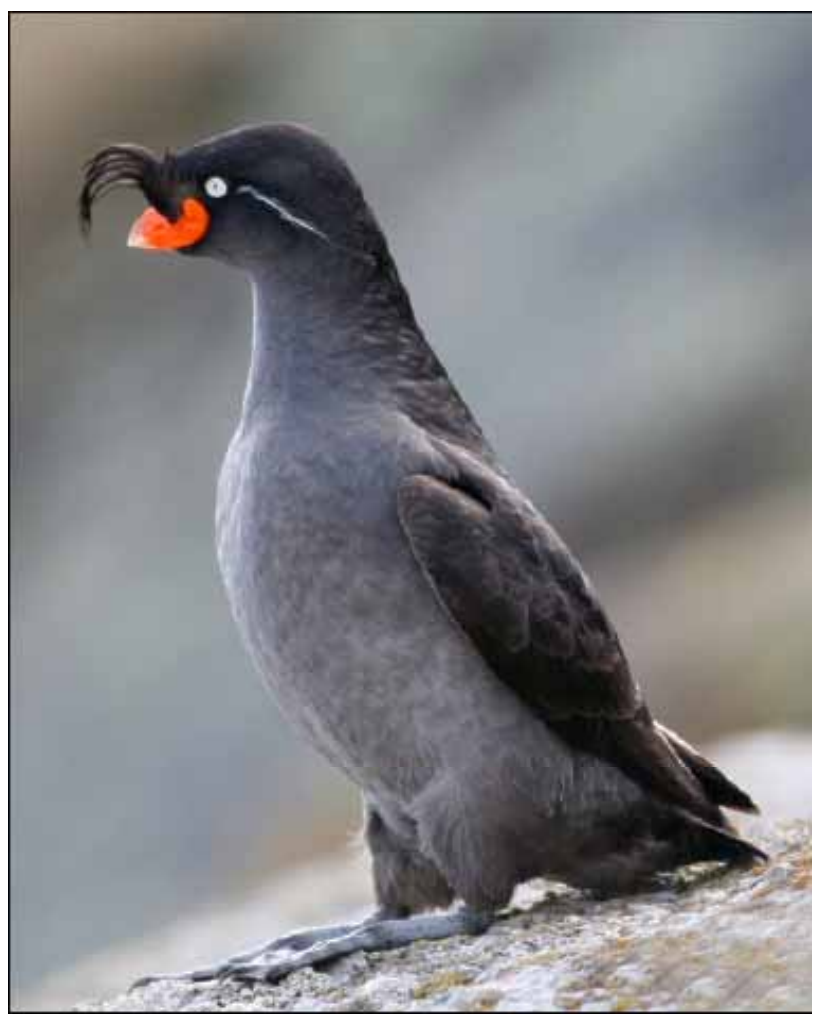

Fig. (1). Crested Auklets (Aethia cristatella), such as the one shown here, emit a citrus-like odor that may deter ectoparasites. Photo by Hector Douglas. 
significantly faster from artificial hosts treated with $10 \%$ octanal than from artificial hosts treated with ethanol. Ticks were also exposed to a synthetic cocktail designed to mimic the diverse chemical composition of auklet odorant. Ticks challenged with this cocktail (40\% octanal, $21 \%$ hexanal, $8 \%$ Z-4 decenal, 3\% decanal, $7 \%$ hexanoic acid, and 3\% octanoic acid) showed a dose dependent response. Ticks exposed to at least a $10 \%$ dilution of the cocktail remained attached to the artificial host for a shorter period of time than controls. Douglas et al. [84] also conducted experiments with Ixodes uriae, the tick found on Crested Auklets in nature. The results were similar to the experiments conducted with $A$. americanum. Moreover, when these ticks were placed in a vial with $5 \mu$ l octanal, they became moribund within an hour.

In another study involving I. uriae ticks, Douglas [86] quantified the relative odor emissions from 57 live Crested Auklets. Interestingly, the individual with the lowest emission level was infested with 14 ticks. Only one other bird was infested (with two ticks), out of 96 birds surveyed in the same breeding colony. In contrast, Hagelin [87] found no evidence that $I$. uriae ticks are repelled by fresh Crested Auklet feathers placed in petri dishes, compared to feathers of Least Auklets or Parakeet Auklets (A. psittacula), neither of which emit a noticeable odor.

Hagelin and Jones [81] have argued that the repellency studies conducted by Douglas et al. [84] used synthetic compounds that exceed natural concentrations (c.f. those measured in auklet odorant by Hagelin et al [88]). In response, Douglas [89] argued that Hagelin et al.'s study underestimated the quantity of volatiles in auklet feathers because the samples were kept under suboptimal conditions, during which time they may have degraded (and see Hagelin [90]).

Douglas [91] published data indicating that natural concentrations of auklet odor are, at least in some cases, greater than those published by Hagelin et al [88]. He also conducted in vitro experiments with ticks (A. americanum) exposed to low doses $(0.5 \%$ and $1 \%)$ of a synthetic cocktail. Douglas [91] argued that these doses simulate natural conditions because the $1 \%$ solution exposed ticks to lower concentrations of octanal than he isolated from the crown and nape feathers of Crested Auklets. Locomotion of ticks at both doses in this study was significantly less than that of controls, and there was evidence of paralysis in some of the ticks exposed to the $1 \%$ treatment. These results suggest that the compounds in Crested Auklet odorant do have the potential to deter ticks. What is needed for a more definitive study, if possible, is a test of the impact of the odorant on ticks under natural conditions in the field. Ideally, this test would involve some kind of experimental manipulation of odorant levels. Tests for an impact of odorants on ectoparasites in other groups of birds are also needed.

\section{Uropygial Oil}

Most birds have a nipple-like uropygial (preen) gland on their rump. They squeeze this protuberance with their bill during preening and spread its oil throughout the plumage. The oil is known to help maintain plumage strength and flexibility, but it has long been thought that the oil may also deter ectoparasites [77, 92, 93]. Uropygial oil could combat ectoparasites by reducing their mobility on feathers or skin. If the oil coats the exterior of a parasite, or at least plugs the spiracles (breathing holes) of arthropod parasites, it might also suffocate them [94]. In some species of birds the oil is associated with noxious or repellent odors, which could conceivably affect ectoparasites [73].

Moyer et al. [94] tested whether preen oil helps Rock Pigeons combat feather lice. They compared the survival of lice raised in an incubator on feathers treated with uropygial oil to the survival of lice on control feathers without oil. They found that lice on oiled feathers died more rapidly than controls. They also compared the population dynamics of lice on captive pigeons with intact uropygial glands to lice on pigeons with their glands surgically removed. Removal of the gland had no significant effect on louse populations over a period of four months (about 5 louse generations). This finding suggests that birds do not "fumigate" themselves with preen oil, despite the fact that the oil does, in fact, have the capacity to kill lice when applied in vitro [94].

Uropygial oil may inhibit the growth of certain pathogenic bacteria and fungi that inhabit the plumage of birds [11,95-99]. Jacob et al. [99] demonstrated that constituents of Pelecaniform uropygial oil, applied in vitro, have a dosedependent inhibitory effect on Gram-positive bacteria and fungal dermatophytes (Trichophyton sp., Microsporum gypseum). The Red-billed Woodhoopoe (Phoeniculus purpureus), like other species of woodhoopoes, emits a malodorous secretion from its uropygial gland [73]. Law-Brown [98] identified 17 chemical constituents found in the uropygial oil of this species. Using disc-diffusion assays, she tested the in vitro activity of each constituent against 13 pathogenic bacterial strains (e.g., Salmonella enteritidis, Staphylococcus aureus, and Streptococcus faecalis), and against a strain of the feather-degrading bacterium Bacillus licheniformis [30]. Seven of the constituents significantly inhibited bacteria, suggesting that uropygial oil has the potential to combat bacterial infections and concommitant feather degradation.

Interestingly, most of the chemical constituents of the uropygial oil of Red-billed Woodhoopes are synthesized by yet another bacterium, Enterococcus phoeniculicola, which lives in the bird's uropygial gland. Law-Brown [98] treated the glands of this species with an antibiotic, and then compared the chemical composition of their uropygial oil to that of untreated controls. Her results showed that only two of 17 constituents were still present following antibiotic treatment. Furthermore, the ones that remained in the oil (e.g., cholesterol) were present at elevated levels, suggesting they were no longer metabolized in the absence of the bacteria. This pioneering study is the first to document a bacterial symbiont that metabolizes constituents of uropygial oil.

Uropygial oil affects different strains of parasitic bacteria and fungi in different ways. Pugh and Evans [96] tested the impact of European Starling (Sturnus vulgaris) "feather fats" on four species of keratinophilic fungi. They made the interesting observation that, while sporulation of Chrysosporium keratinophilum increased, the same oils inhibited the growth of Arthroderma quadrifidum, A. uncinatum and Ctenomyces serratus. Pugh [11] found that the feather fats of Blackbirds (Turdus merula) inhibited the growth of $C$. serratus, while stimulating the growth of $A$. curreyi. In a similar study, Bandyopadhyay and Bhattacharyya [100] tested the effects of uropygial oil on several fungal species cultured from the skin 
of white leghorn fowl. They found that surgical removal of the uropygial gland led to an increase in the populations of all but one species of fungi.

Shawkey et al. [101] suggest that uropygial oil might benefit birds by promoting the growth of bacteria or fungi that out compete or otherwise exclude more virulent microbes. The authors identified 13 bacterial isolates from the feathers of wild house finches (Carpodacus mexicanus), and measured the feather-degrading activity of each. They tested the effects of uropygial oil on the survival and growth of each strain through a disc-diffusion assay. They found that uropygial oil inhibited the growth of three feather degrading strains, including Bacillus licheniformis, but it had less of an effect on more benign strains. Future studies should aim to clarify the impact of uropygial oil on bacterial and fungal strains both in isolation, and in the context of the full microbial community.

Feather mites may have an entirely different relationship with uropygial oil. Blanco et al. [102] suggested that feather mites are commensals, or even mutualists, rather than parasites. The main food resource of certain feather mites is uropygial oil on the feathers. Along with the oil, the mites consume microbes such as fungi and bacteria [9]. If these microbes include forms that are dangerous to the bird, the consumption of uropygial oil by feather mites may be beneficial to the host $[103,104]$. This interesting hypothesis should be tested experimentally.

\section{BODY MAINTENANCE BEHAVIOR}

Grooming behavior, defined as preening and scratching combined [105], is known to be critical for defense against ectoparasites [5, 24]. Preening is of two types: self-preening (Fig. 2a) and allopreening (Fig. 2b). Water bathing, dusting, sunning, anointing and cosmetic behaviors may also play a role in ectoparasite defense. Below we review the evidence relevant to each of these behaviors, as well as the evidence relevant to the different types of grooming.

\section{Grooming: Self-Preening}

Preening is the most common defensive behavior that birds use against ectoparasites. Preening involves the bird pulling its feathers between the two mandibles of the bill, or nibbling the feathers with the bill tips. Birds can spend a significant portion of their daily time budget preening; e.g. Losito et al. [106] showed that juvenile mourning doves spend up to $23 \%$ of their time preening. This is a considerable amount of time and energy, given that the cost of preening can be about twice the basic metabolic rate [107]. Croll and McLaren [108] documented a nearly $200 \%$ increase in the metabolic rate of preening Thick-billed Murres (Uria lomvia), compared to resting individuals. The increase was higher than that associated with either feeding (49\%) or diving $(140 \%)$.

Many studies have shown that preening is a critical defense against ectoparasites. The defensive role of preening was initially suggested by natural "experiments" in which birds with bill deformities have very high ectoparasite loads [4, 5, 31, 34, 36, 109-113]. For example, Clayton et al. [113] observed that among 150 wild Rock Pigeons, the three individuals with the most feather lice all had minor bill deformi-
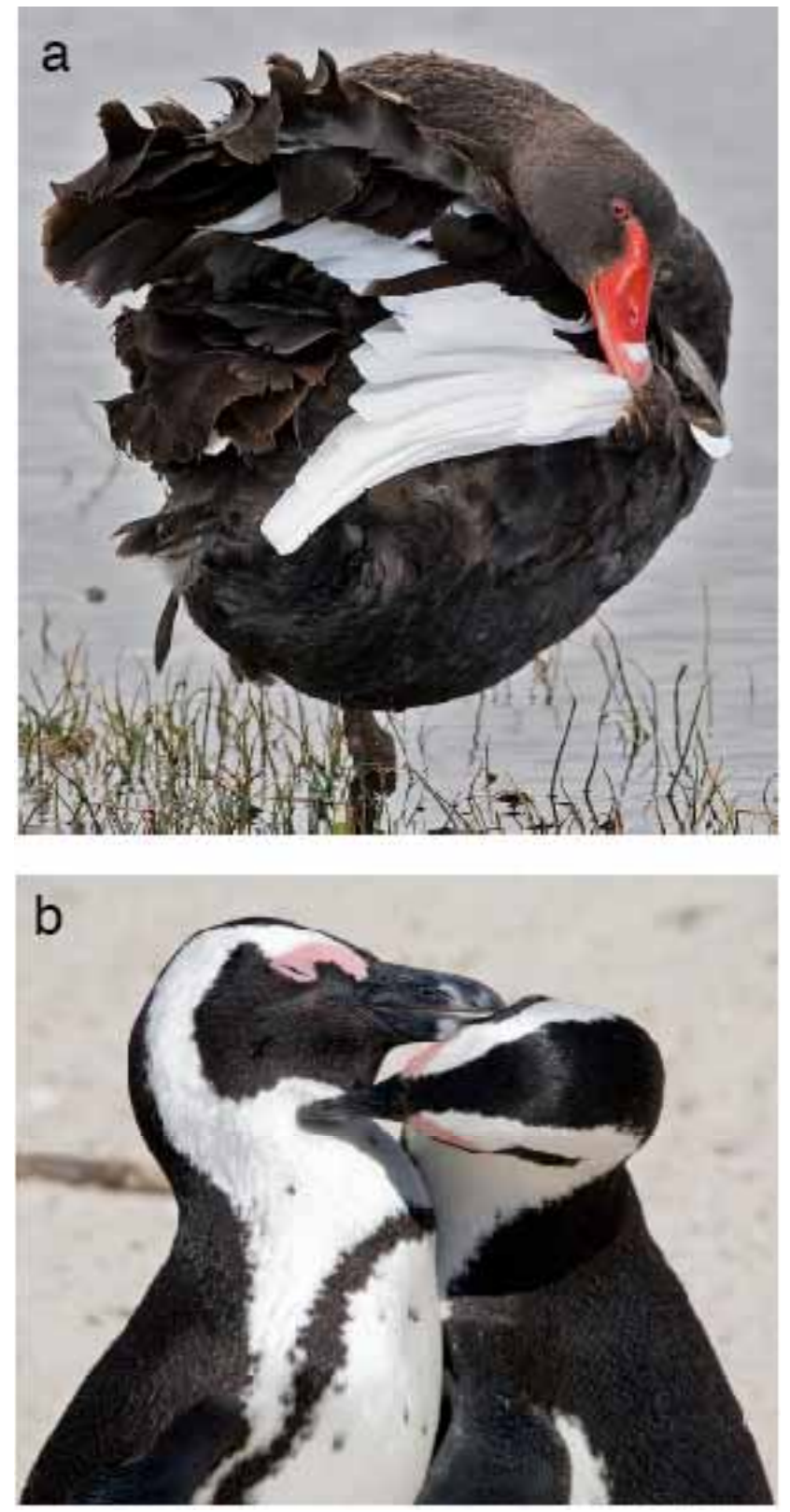

Fig. (2). (a) Preening Black Swan (Cygnus atratus). Photo by Noodle Snacks (commons.wikimedia.org). (b) Allopreening between Magellanic Penguins (Spheniscus magellanicus). Photo by Andreas Edelmann (fotolia.com).

ties. One of the deformed individuals had more than 10,000 lice, compared to a mean of 631 lice on birds without deformities. Of course, birds with deformed mandibles may have other problems, such as impaired foraging ability, which could contribute to increases in ectoparasite load [114-117]. Therefore, a rigorous test of the role of preening in ectoparasite control requires an experimental approach that alters only preening efficiency.

Early such tests impaired preening crudely by clipping ca. $1 \mathrm{~cm}$ from the upper mandible of domestic chickens or pigeons, leading to dramatic increases in ectoparasite load [118-121]. Subsequent tests impaired preening in a less invasive way, using poultry "bits," which are small, C-shaped 
pieces of metal or plastic. Bits are inserted between the upper and lower mandibles and crimped slightly in the nostrils to prevent dislodging, but without damaging the tissue. They create a 1-3 mm gap between the mandibles that impairs the forceps-like action of the bill required for efficient preening. Bitting triggers a dramatic increase in feather louse populations on pigeons $[112,113,122,123]$. This increase is not due to side effects of bits, such as an impact on feeding, because pigeons feed on whole grain (corn, peas, etc.) that can be picked up despite the small mandibular gap created by the bits. Clayton and Tompkins [123] showed that bits have no effect on the survival or reproductive success of (unparasitized) Rock Pigeons, compared to non-bitted controls.

The importance of preening for ectoparasite control is also apparent from comparative studies. The size of the bill overhang varies markedly across species of birds (Fig. 3). For example, Clayton and Walther [124] compared the diversity of lice among 52 species of Peruvian birds belonging to 13 families. Phylogenetically independent comparisons revealed a significant negative correlation between louse abundance and degree to which the upper mandible (maxilla) overhangs the lower mandible. This correlation suggests that birds with slightly longer overhangs are better at controlling lice by preening. Extreme overhangs, such as the hooked bills of raptors and parrots, are adaptations for feeding that do not enhance preening efficiency [124].

Clayton et al. [125] demonstrated how the maxillary overhang functions to control lice. Experimental removal of the tiny (1-2 mm) overhang (Fig. 3e,f), triggered a dramatic increase in louse population size (Fig. 4a). Regrowth caused the louse populations to subsequently crash (Fig. 4a). In a series of measurements using magnetic transducers glued to the mandibles of birds, the authors showed that the lower mandible moves forward during preening (Rock Pigeon preening at $1 / 4$ th actual speed, Rock Pigeon preening at 1/24th actual speed) (suppl 1). This forward motion, which was remarkably fast, at up to 31 times per second, created a shearing force against the overhang that damaged the lice (Fig. 4b-e). Without the maxillary overhang, birds were unable to generate this force. Additional experiments showed that removal of the overhang had no impact on feeding efficiency, suggesting that the overhang is a specific adaptation for ectoparasite control. Overhangs longer than a mean of $1.5 \mathrm{~mm}$ broke significantly more often than shorter overhangs, further suggesting that stabilizing selection favors overhangs of intermediate length. Considering the critical
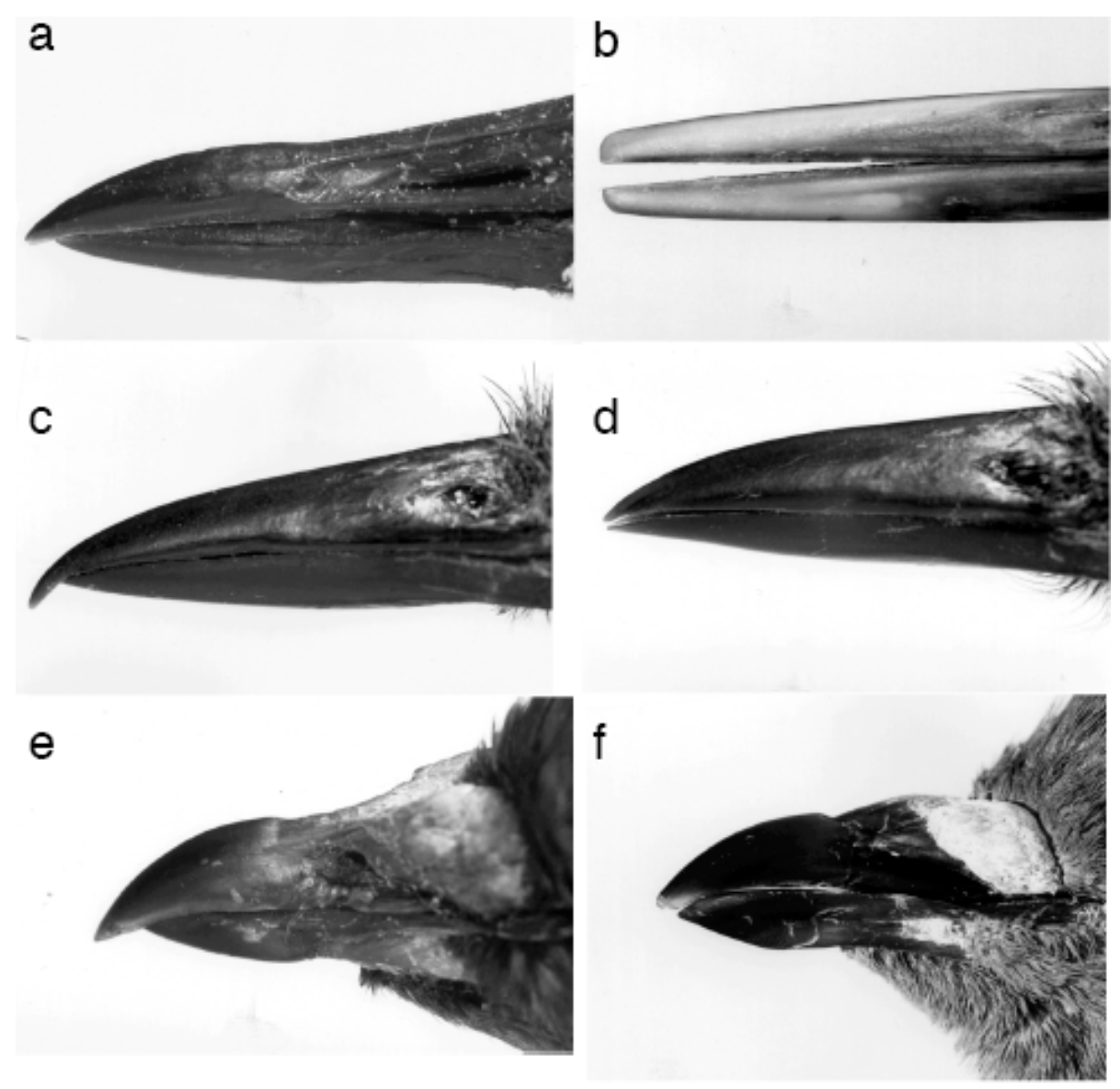

Fig. (3). Natural and experimentally induced variation in the bill overhang. Within the family Charadriidae, the Black-bellied Plover (Pluvialis squatarola) has a pronounced overhang (a), whereas the Black Oystercatcher (Haematopus bachmani) lacks an overhang (b). Within the species Western Scrub-Jay (Aphelocoma californica), populations living in scrub oak have a pronounced overhang (c), whereas those living in pinyon pine have no overhang (d). Rock Pigeons (Columba livia) have a pronounced overhang (e), which Clayton et al. [125] trimmed using a Dremel ${ }^{\circledR}$ rotary tool (f). Trimming is a harmless procedure, and the overhang regrows in $1-2$ weeks. The results of trimming are shown in Fig. (4). Photos by C. Beittel. 

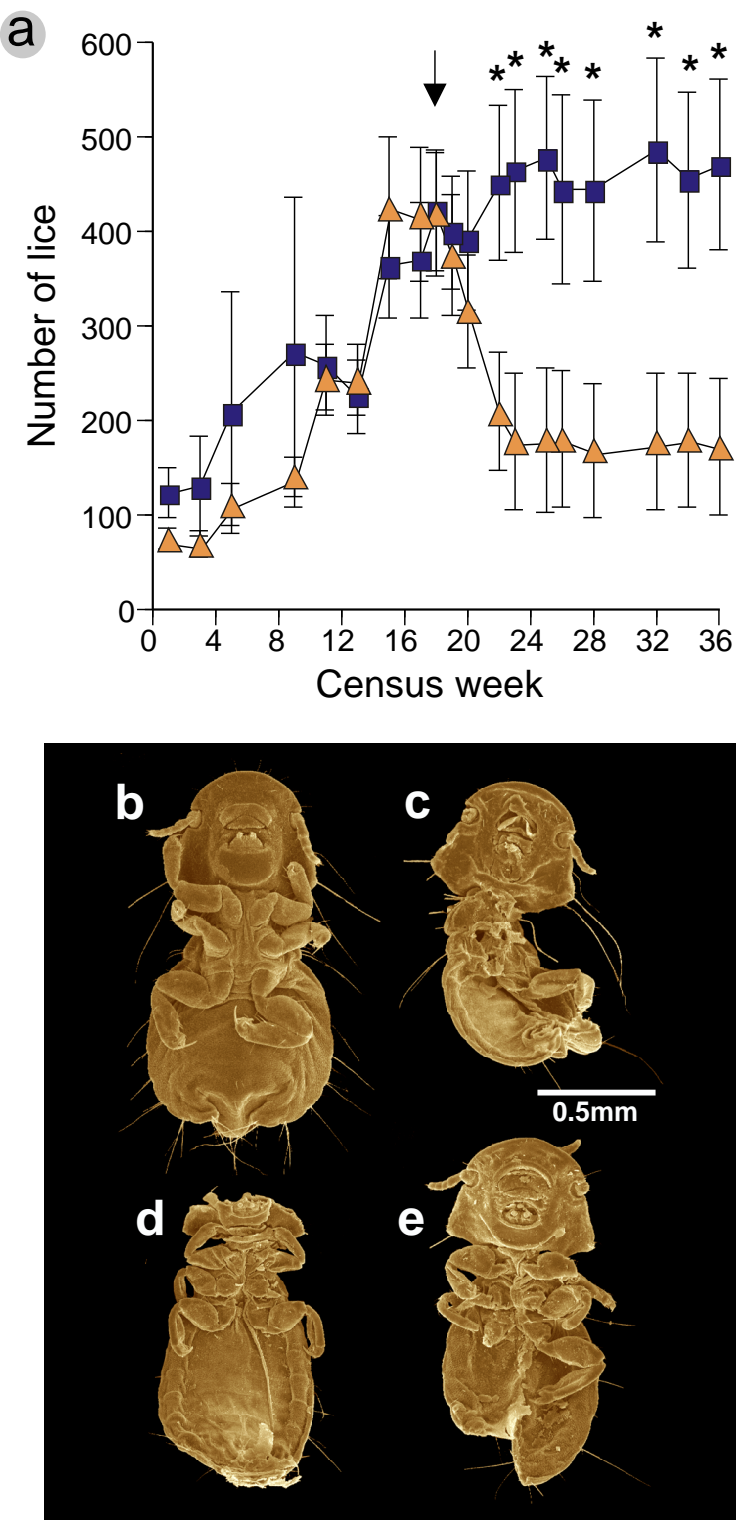

Fig. (4). (a) Mean ( \pm 1 SE) number of lice on 26 adult pigeons in an experiment to test the impact of the bill overhang on preening efficiency. The overhangs of all birds were trimmed for 17 weeks; at week 18 (arrow), half the birds (orange triangles) were allowed to regrow their overhangs, while the remaining half (blue squares) continued to be trimmed weekly. Data were analyzed using a 2 (treatment: trim, regrow) X 11 (post-treatment census) ANOVA with repeated measures on the second factor (census). There were significant overall effects of treatment $(P=0.003)$ and census $(P<$ $0.0001)$, and a significant interaction $(P<0.0001)$. Birds allowed to regrow their overhangs had significantly fewer lice than trimmed birds at each of the final eight censuses $=$ weeks 22-36 (Protected $t$ $>1.97$, df $=240, * P<0.001$ ). (b) SEM of an undamaged louse (Campanulotes compar), compared to lice that have had most of their legs removed $(\mathbf{c})$, or been decapitated (d), or lacerated (e) by birds with normal overhangs. Reprinted from Clayton et al. [125].

importance of the maxillary overhang for controlling lice, Clayton et al. [125] concluded that the adaptive radiation of beak morphology in birds should be re-assessed with both feeding and preening in mind.
Interestingly, a negative correlation between length of the bill overhang and ectoparasite abundance is also apparent among populations within species. Populations of the Western Scrub-jay (Aphelocoma californica) have bills specialized for feeding in their respective habitats [126, 127]. Scrub-jays in oak habitat have hooked bills (Fig. 3c), whereas the bills of populations in pinyon habitat are pointed (Fig. 3d). Moyer et al. [128] quantified lice on 170 freshly collected jays and found a significant relationship between bill morphology and louse load. Although louse prevalence was low, infested birds with pointed bills had significantly more lice than infested birds with hooked bills. More recent work using better methods of quantifying parasites further suggests that lice also exert stabilizing selection on the bill morphology of jays (Fig. 5).

\section{Grooming: Allopreening}

In addition to preening themselves, birds sometimes "allopreen" one another (Fig. 2b). Allopreening helps reduce ectoparasites on the head and neck, which are impossible to self-preen. Allopreening is a widespread behavior observed in many species of birds [129]. It is most common between courting and mated individuals, and between parents and their offspring. Harrison [129] argued that allopreening serves mainly a social function, such as reinforcement of the pair bond, and is of little or no importance for ectoparasite control. However, subsequent studies indicate a role for allopreening in parasite control [130-133]. Radford and Du Plessis [134] suggested a dual function for allopreening in the Green Woodhoopoe (Phoeniculus purpureus). Allopreening of the head and neck regions occurs at similar rates for dominant and subordinate individuals, suggesting a hygienic function. However, allopreening of self-accessible body regions, such as the wings, back or breast, are influenced by group size and dominance status, suggesting a social function.

Among the most convincing demonstrations of the importance of allopreening for controlling parasites is Brooke's [131] study of tick-infested Macaroni Penguins (Eudyptes chrysolophus). Brooke reported that individual birds, which could only self-preen, had two to three times more ticks than paired birds, which engaged in frequent allopreening. The ticks were found mainly on the head and neck, suggesting that the larger numbers on unpaired birds were due to the lack of allopreening, rather than inefficient self-preening. It is important to keep in mind, however, that the author could not control for possible covariates of tick load, such as genetic resistance. Such resistance, if present, might have contributed to the low tick loads of some individuals, as well as to their ability to attract mates. Hence, inability to attract mates could lead to a spurious inverse correlation between tick load and allopreening. A more rigorous test of the role of allopreening requires analysis of covariation between allopreening and parasite load [cf. 135] or - even better - experimental manipulation of allopreening and its impact on ectoparasites.

\section{Grooming: Scratching}

Scratching with the feet is an important means of controlling ectoparasites on regions that cannot be self-preened, such as the head. Birds with a deformed or missing foot of- 

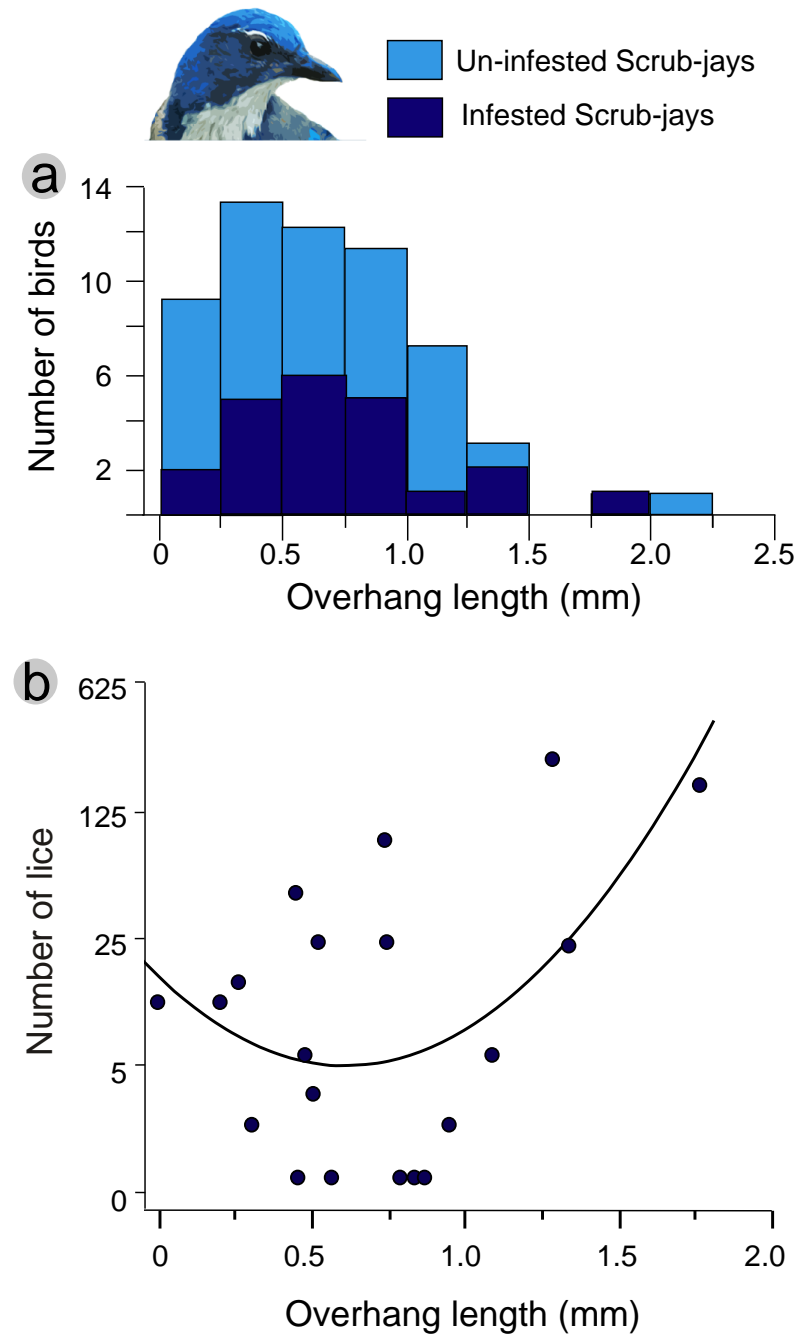

Fig. (5). Overhang lengths of Western Scrub-jays, in relation to ectoparasite abundance. Jay specimens $(n=57)$ were collected in 2002-03 at five localities in Utah and Nevada (Utah: Oquirrh Mountains, $n=8$; Lookout Pass, $n=4$; La Sal National Forest, $n=$ 6, Stansbury Mountains, $n=2$; Nevada: vicinity of Austin, $n=37$ ). Bills were measured with calipers and the number of lice on each bird was determined using the body washing method [41]. Panel (a) shows the distribution of overhang length (mean of three measurements per bird) across all 57 birds, as well as across the 20 birds (35\%) that were infested with lice. Factors other than preening, such as ambient humidity, are known to influence the prevalence of feather lice on Western Scrub-jays [38]. Nevertheless, of the twenty birds that had lice, those with intermediate overhangs had the fewest lice (Fig. 5b; quadratic regression $\mathrm{R}^{2}=0.30, P<0.05$ ). This intriguing relationship suggests that lice exert stabilizing selection for intermediate overhang length, presumably because intermediate overhangs are best at controlling lice (cf. Clayton et al. [125]). An experimental test of this hypothesis is needed.

ten have large numbers of ectoparasites (and their eggs) concentrated around the head and neck [112]. The obvious explanation is that, although birds can preen themselves while standing on one leg, they cannot scratch themselves. Although the precise impact of scratching on ectoparasites has not been measured, scratching is known to kill or damage fleas on domestic chickens (Suter cited in Marshall [5]).
Birds may use scratching to compensate for a lack of other methods of ectoparasite control. The unpaired penguins in Brooke's [131] study spent significantly more time scratching than did paired individuals with access to allopreening. Scratching also appears to compensate for inefficient preening in species with unwieldy bills. Clayton and Cotgreave [105] reported that long-billed species average $16.2 \%$ of their grooming time scratching, compared to $2.3 \%$ in short-billed species. In a series of paired taxonomic comparisons, long-billed species scratched significantly more than short-billed taxa. In another comparative study, Clayton and Walther [124] investigated the relationship of relative foot length and toenail flange width to the louse loads of Peruvian birds, but neither feature was correlated with louse species richness or abundance.

The efficiency of scratching for ectoparasite control may be enhanced by the presence of a comb-like pectinate claw on the middle toes of some birds (Fig. 6) [136-138]. But the possible ectoparasite control function of this "louse comb" has long been controversial [139]. Other possible functions include a role in feeding [140], removal of stale powder down from the plumage [141], or straightening of rictal bristles [137, 142]. To our knowledge, however, none of these functional hypotheses, including ectoparasite control, has ever been tested. Even the distribution of the pectinate claw among bird taxa has not been carefully documented.

One of us (BRM) recently examined 1421 study skins for pectinate claws in the collection of the Division of Birds, National Museum of Natural History, Washington DC. At
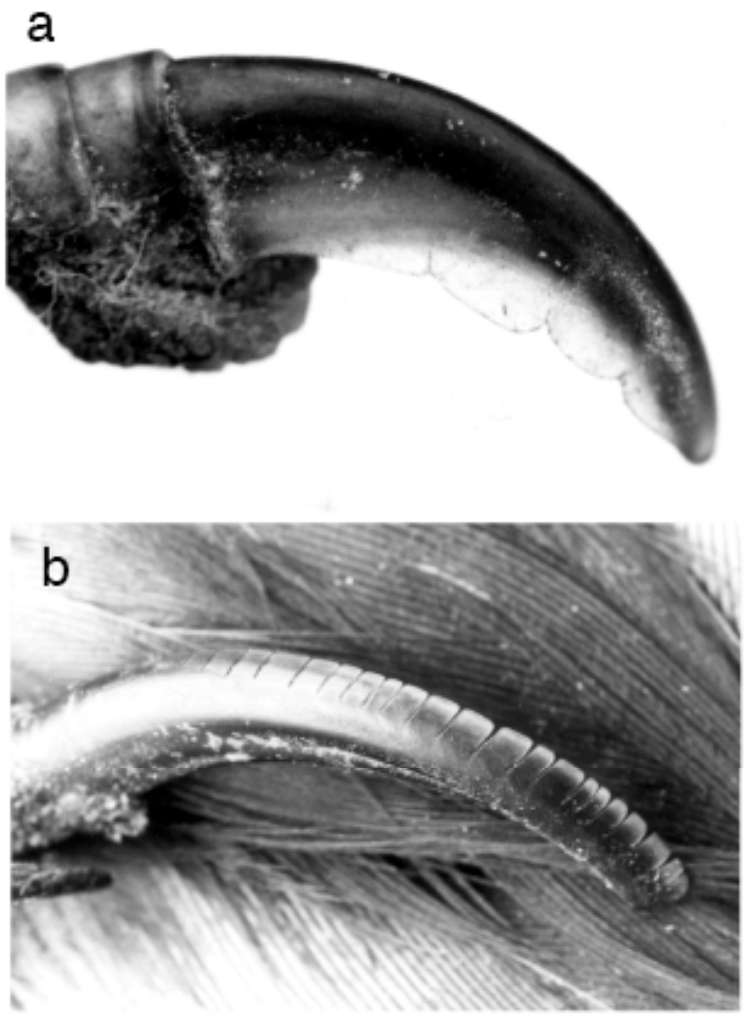

Fig. (6). Variation in the structure of the pectinate claw, ranging from (a) the coarsely serrated claw of the American Dipper (Cinclus mexicanus) to (b) the finely serrated claw of the Magnificent Frigatebird (Fregata magnificens). Photos by C. Beittel. 
least one representative species from each of 118 (82\%) of the 144 bird families recognized by Sibley and Ahlquist [143] was selected (haphazardly), and all of the claws of one male and one female specimen were examined under $6 x$ magnification. Skins of species noted in the literature to have a pectinate claw were also examined $[138,144-146]$. A pectinate claw was considered to be present if any portion of any claw was serrate. If a pectinate claw was detected in a given family during the initial survey, at least one representative species from every available genus in this family was subsequently examined to assess within family variation (5 males and 5 females were examined when possible).

Most birds lack a pectinate claw. Only 17 of 118 families contained individuals with pectinate claws (Table I), and of the Passeriformes, only dippers (Cinclidae) had them (Fig 6a). The claw has probably evolved repeatedly, given its scattered distribution across bird families. It is also variable within families; only a minority of genera possess it within most of the 17 families. For example, a pectinate claw is present in one of four genera of Heliornithidae, two of 12 genera of Scolopacidae, four of six genera of Glareolidae, four of 16 genera of Laridae, and one of ten genera of Threskiornithidae (Table I).

In addition to within-family variation, we discovered within-species variation in pectinate claws. In 15 species some individuals had the claw, while others lacked it (Table I). This intraspecific variation did not appear to be related to the sex, geographic distribution, or season in which the bird was collected. We did not examine variation in relation to the bird's age, but this would also be interesting to explore. The structure of the pectinate claw varied considerably among taxa. Pectinations ranged from scalloping, as in the American Dipper (Cinclus mexicanus) (Fig. 6a), to fine serrations, as in the Magnificent Frigatebird (Fregata magnificens) (Fig. 6b).

Serrations on some pectinate claws are somewhat similar to the teeth of combs designed to remove human head lice. Clay [138] believed that species with pectinate claws might be more efficient at removing lice from the head by scratching. She predicted that birds with pectinate claws would be parasitized by fewer species of head lice than those species without pectinate claws. We tested Clay's hypothesis using an analysis that compared the species richness of head lice on birds with pectinate claws to that of sister taxa without pectinate claws. We selected 14 phylogenetically independent comparisons of bird species with and without pectinate claws. We then asked a louse taxonomist colleague to tally the number of species of head lice known from each species of bird using Price et al. [63]. Because louse species richness is influenced by sampling effort, we corrected for this factor as described in Walther et al. [147].

Our analysis revealed no significant difference in the number of species of head lice on birds with and without claws (Wilcoxon signed-rank test on residuals, $\mathrm{T}=24.5, P=$ 0.15 ). In eight of the 14 comparisons, the species with the pectinate claw had fewer (residual) species of head lice, and in five comparisons the reverse was true (one tie). In retrospect, it is unclear why one should necessarily expect a negative correlation between the pectinate claw and louse species richness, or a positive correlation. If richness decreases on birds that evolve pectinate claws, then selection maintaining the claw would be relaxed, leading to disappearance of the claw. Hence, this comparative analysis is perhaps not the most convincing test of the hypothesis that pectinate claws help to control ectoparasites.

We have also investigated the relationship between louse abundance and pectinate claw morphology within species. We used 24 road-killed Barn Owls (Tyto alba) salvaged by colleagues along highways in southern Idaho. We counted the number of teeth on the pectinate claw of each foot (Fig 7a), and we measured the length and width of each claw's flange. The number of lice on each owl was quantified using "body washing" [41]. Fourteen (58\%) of the owls had lice, but one was missing the pectinate claw on one foot. Since we could not be sure whether this was natural, or a consequence of post-mortem road damage, this individual bird was excluded from the analysis.

There was no significant difference in the number of teeth or the length or width of the flange, between infested and uninfested owls $(n=23, d f=1, P>0.27)$. Similarly, there was no significant relationship between the abundance of lice on infested owls, and the mean number of teeth per claw (Fig. 7c). Finally, there was no relationship between louse abundance and mean claw length $\left(n=13, \mathrm{R}^{2}=0.006\right.$, $P=0.81)$, or width $\left(n=13, \mathrm{R}^{2}=0.02, P=0.63\right)$. The results of this study indicate that natural variation in the size and shape of the pectinate claw does not correlate with louse prevalence or intensity, at least in the case of Barn Owls from southern Idaho.

In summary, these comparative and correlational studies indicate that the pectinate claw plays no role in parasite control. However, a more definitive test would be to conduct an experiment in which parasite populations are monitored on birds with normal claws, versus birds from which the pectinations have been removed, perhaps by filing them off. There are several common species that could be used for this experiment, such as Cattle Egrets (Bubulcus ibis) (Table I).

\section{Bathing}

Another form of maintenance behavior practiced by most birds is bathing in water.

Rothschild and Clay [4] wrote, "Bathing in water and dust and the subsequent preening helps the bird to rid itself of parasites." However, we are not aware of any evidence suggesting that water bathing has a detrimental effect on ectoparasites. If anything, it might be expected to have a positive effect, given that high humidity favors ectoparasites ranging from feather lice [37] to bacteria [70]. It is conceivable that substances detrimental to ectoparasites might be dissolved in some water sources, but we know of no support for this speculation.

\section{Dusting}

Members of at least a dozen orders of birds are known to engage in dusting (Table II), during which fine dirt or sand is ruffled through the plumage [148-150] (Fig. 8). Dusting appears to remove excess feather oil that can cause matting of plumage [151-153]. It is also thought to help control ectoparasites. Several mechanisms for such control have been proposed, including (1) reducing feather lipids upon which some ectoparasites feed [152]; (2) directly dislodging para 
Table I. Occurrence of Pectinate Claws Among 1421 Study Skins of Birds Representing 278 Species in 250 Genera (118 Families, 23 Orders). Species with Pectinate Claws are in Boldface. Presence (+) or Absence (-) of a Maxillary Overhang on the Bill is also Indicated in the Final Column; Lack of a Symbol Means the Species was not Checked for an Overhang. Classification and Nomenclature Follow Sibley and Monroe [252]

\begin{tabular}{|c|c|c|c|}
\hline Higher Taxa & Bird Species & $\begin{array}{l}\text { \# With Claw/ } \\
\text { \# Examined (\%) }\end{array}$ & $\begin{array}{l}\text { Bill Overhang } \\
\text { Present (+), Absent (-), or } \\
\text { Unexamined () }\end{array}$ \\
\hline Struthionidae & Ostrich, Struthio camelus & $0 / 2(0)$ & + \\
\hline \multirow[t]{2}{*}{ Casuariidae } & Dwarf Cassowary, Casuarius bennetti & $0 / 2(0)$ & + \\
\hline & Emu, Dromaius novaehollandiae & $0 / 2(0)$ & + \\
\hline Apterygidae & Brown Kiwi, Apteryx australis & $0 / 2(0)$ & + \\
\hline \multicolumn{4}{|l|}{ Tinamiformes } \\
\hline \multicolumn{4}{|l|}{ Craciformes } \\
\hline \multirow[t]{2}{*}{ Cracidae } & Grey-headed Chachalaca, Ortalis cinereiceps & $0 / 2(0)$ & + \\
\hline & Blue-knobbed Curassow, Crax alberti & $0 / 2(0)$ & \\
\hline Megapodiidae & Brown-collared Brush-turkey, Talegalla jobiensis & $0 / 2(0)$ & + \\
\hline \multicolumn{4}{|l|}{ Galliformes } \\
\hline \multirow[t]{2}{*}{ Phasianidae } & Green Peafowl, Pavo muticus & $0 / 2(0)$ & \\
\hline & Spruce Grouse, Dendragapus canadensis & $0 / 2(0)$ & + \\
\hline Anhimidae & Southern Screamer, Chauna torquata & $0 / 2(0)$ & + \\
\hline \multirow[t]{2}{*}{ Anatidae } & Emperor Goose, Anser canagica & $0 / 2(0)$ & + \\
\hline & Common Teal, Anas crecca & $0 / 2(0)$ & \\
\hline \multicolumn{4}{|l|}{ Turniciformes } \\
\hline Turnicidae & Barred Buttonquail, Turnix suscitator & $0 / 2(0)$ & + \\
\hline \multicolumn{4}{|l|}{ Piciformes } \\
\hline Indicatoridae & Lesser Honeyguide, Indicator minor & $0 / 2(0)$ & + \\
\hline \multirow[t]{2}{*}{ Picidae } & Black-cheeked Woodpecker, Melanerpes pucherani & $0 / 2(0)$ & \\
\hline & Greater Flameback, Chrysocolaptes lucidus & $0 / 2(0)$ & - \\
\hline Lybiidae & Green Barbet, Stactolaema olivacea & $0 / 2(0)$ & + \\
\hline Ramphastidae & Yellow-eared Toucanet, Selenidera spectabilis & $0 / 2(0)$ & + \\
\hline Galbuliformes & & & \\
\hline
\end{tabular}


Table 1. Contd....

\begin{tabular}{|c|c|c|c|}
\hline Higher Taxa & Bird Species & $\begin{array}{l}\text { \# With Claw/ } \\
\text { \# Examined (\%) }\end{array}$ & $\begin{array}{l}\text { Bill Overhang } \\
\text { Present (+), Absent (-), or } \\
\text { Unexamined ( ) }\end{array}$ \\
\hline Bucconidae & White-whiskered Puffbird, Malacoptila panamensis & $0 / 2(0)$ & + \\
\hline Bucerotidae & White-crowned Hornbill, Aceros comatus & $0 / 2(0)$ & + \\
\hline \multicolumn{4}{|l|}{ Upupiformes } \\
\hline Upupidae & Eurasian Hoopoe, Upupa epops & $0 / 2(0)$ & + \\
\hline Trogonidae & Diard's Trogon, Harpactes diardii & $0 / 2(0)$ & + \\
\hline \multicolumn{4}{|l|}{ Coraciiformes } \\
\hline Coraciidae & Purple-winged Roller, Coracias temminckii & $0 / 2(0)$ & + \\
\hline Leptosomidae & Courol, Leptosomus discolor & $0 / 2(0)$ & + \\
\hline Momotidae & Turquoise-browed Motmot, Eumomota superciliosa & $0 / 2(0)$ & + \\
\hline Todidae & Broad-billed Tody, Todus subulatus & $0 / 2(0)$ & + \\
\hline Dacelonidae & Laughing Kookaburra, Dacelo novaeguineae & $0 / 2(0)$ & + \\
\hline Cerylidae & Belted Kingfisher, Megaceryle alcyon & $0 / 2(0)$ & + \\
\hline \multicolumn{4}{|l|}{ Coliiformes } \\
\hline Cuculidae & Large Hawk-cuckoo, Cuculus sparverioides & $0 / 2(0)$ & + \\
\hline Opisthocomidae & Hoatzin, Opisthocomus hoazin & $0 / 2(0)$ & + \\
\hline \multicolumn{4}{|l|}{ Psittaciformes } \\
\hline Psittacidae & Common Kaka, Nestor meridionalis & $0 / 2(0)$ & + \\
\hline \multicolumn{4}{|l|}{ Apodiformes } \\
\hline Apodidae & White-throated Swift, Aeronautes saxatalis & $0 / 2(0)$ & + \\
\hline Hemiprocnidae & Grey-rumped Treeswift, Hemiprocne longipennis & $0 / 2(0)$ & + \\
\hline \multicolumn{4}{|l|}{ Trochiliformes } \\
\hline Trochilidae & Black-hooded Sunbeam, Aglaeactis pamela & $0 / 2(0)$ & - \\
\hline \multicolumn{4}{|c|}{ Musophagiformes } \\
\hline Musophagidae & Knysna Turaco, Tauraco corythaix & $0 / 2(0)$ & + \\
\hline \multicolumn{4}{|l|}{ Strigiformes } \\
\hline \multirow[t]{2}{*}{ Tytonidae } & Barn Owl, Tyto alba & $12 / 12(100)$ & + \\
\hline & Oriental Bay-Owl, Phodilus badius & $3 / 3(100)$ & \\
\hline
\end{tabular}


Table 1. Contd....

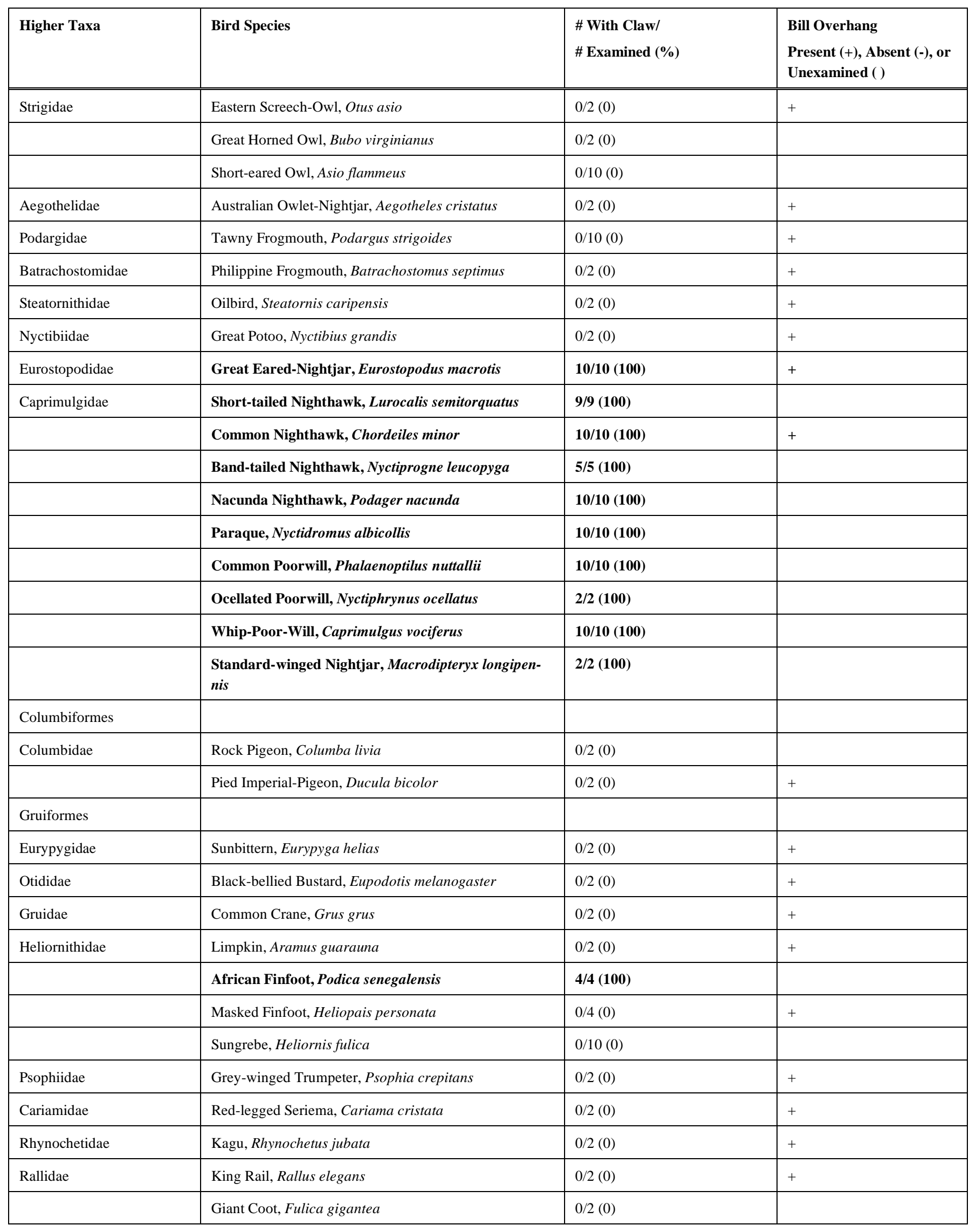


Table 1. Contd....

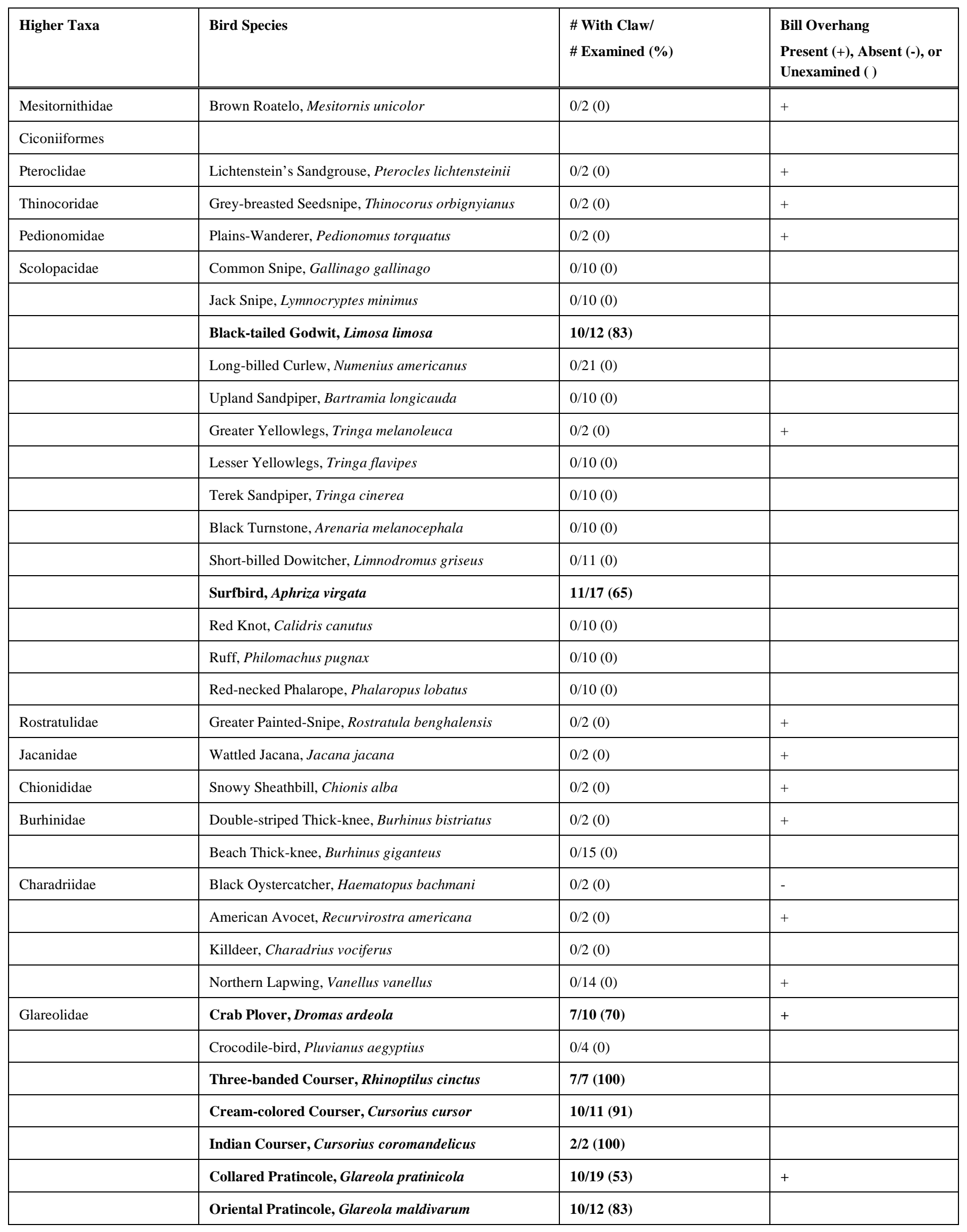


Table 1. Contd....

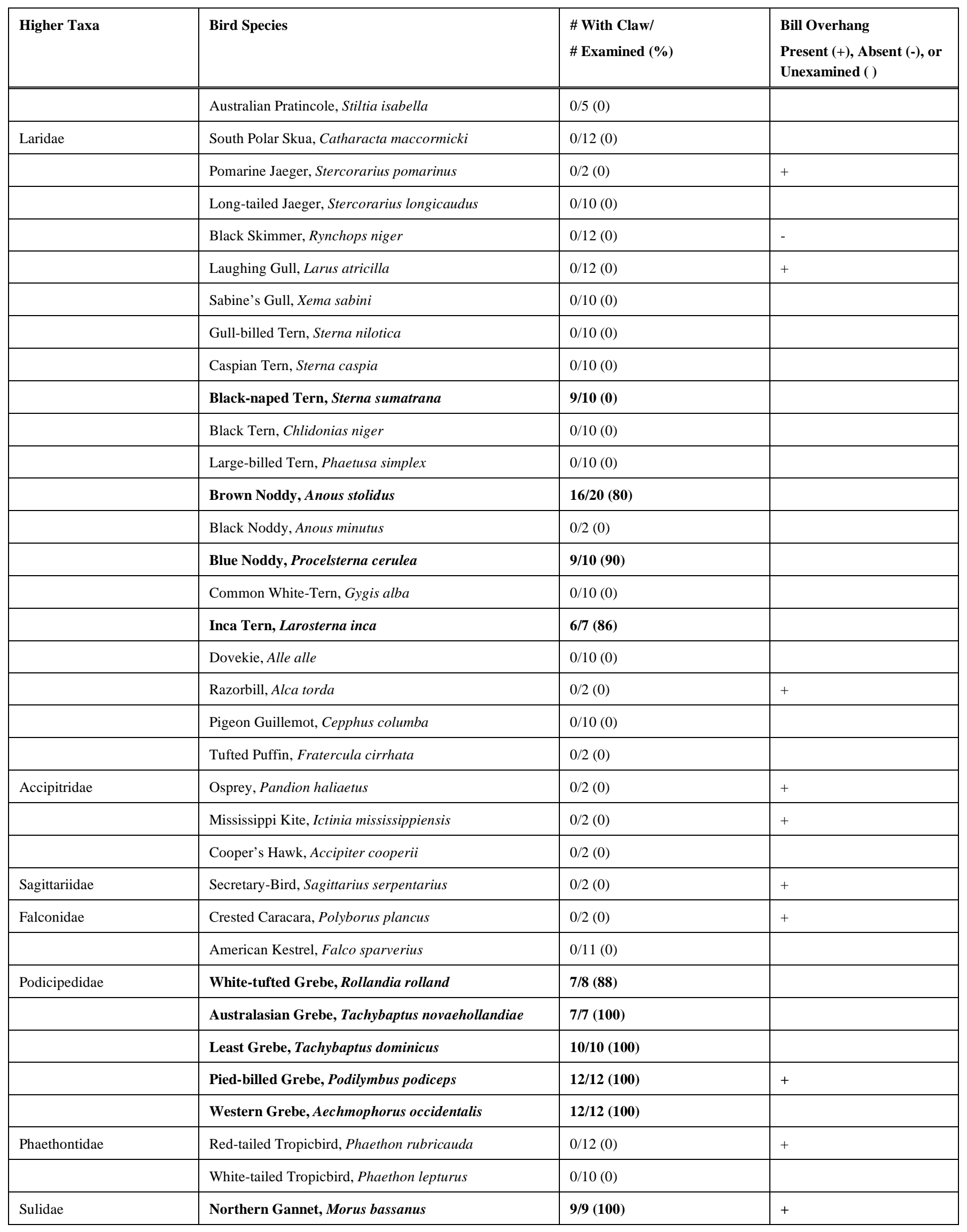


Table 1. Contd....

\begin{tabular}{|c|c|c|c|}
\hline Higher Taxa & Bird Species & $\begin{array}{l}\text { \# With Claw/ } \\
\text { \# Examined (\%) }\end{array}$ & $\begin{array}{l}\text { Bill Overhang } \\
\text { Present (+), Absent (-), or } \\
\text { Unexamined () }\end{array}$ \\
\hline & Brown Booby, Sula leucogaster & 11/11 (100) & \\
\hline Anhingidae & Anhinga, Anhinga anhinga & $10 / 10(100)$ & \\
\hline \multirow[t]{3}{*}{ Phalacrocoracidae } & Little Cormorant, Phalacrocorax niger & $2 / 2(100)$ & \\
\hline & Brandt's Cormorant, Phalacrocorax penicillatus & $10 / 10(100)$ & \\
\hline & Neotropic Cormorant, Phalacrocorax brasilianus & $2 / 2(100)$ & + \\
\hline \multirow{7}{*}{ Ardeidae } & Chinese Pond-Heron, Ardeola bacchus & $10 / 10(100)$ & \\
\hline & Yellow-crowned Night-Heron, Nyctanassa violacea & $10 / 10(100)$ & \\
\hline & Black-crowned Night-Heron, Nycticorax nycticorax & $10 / 10(100)$ & \\
\hline & Boat-billed Heron, Cochlearius cochlearius & $10 / 10(100)$ & \\
\hline & Bare-throated Tiger-Heron, Tigrisoma mexicanum & $10 / 10(100)$ & \\
\hline & White-crested Bittern, Tigriornis leucolophus & $2 / 2(100)$ & \\
\hline & Zigzag Heron, Zebrilus undulatus & $1 / 1(100)$ & \\
\hline \multirow[t]{14}{*}{ Threskiornithidae } & White Ibis, Eudocimus albus & $0 / 10(0)$ & \\
\hline & White-faced Ibis, Plegadis chihi & $12 / 12(100)$ & \\
\hline & Plumbeous Ibis, Theristicus caerulescens & $0 / 5(0)$ & \\
\hline & Buff-necked Ibis, Theristicus caudatus & $0 / 9(0)$ & \\
\hline & Green Ibis, Mesembrinibis cayennensis & $0 / 10(0)$ & \\
\hline & Hadada Ibis, Bostrychia hagedash & $0 / 12(0)$ & \\
\hline & Wattled Ibis, Bostrychia carunculata & $0 / 5(0)$ & \\
\hline & Spot-breasted Ibis, Bostrychia rara & $0 / 1(0)$ & \\
\hline & Bald Ibis, Geronticus calvus & $0 / 2(0)$ & \\
\hline & Sacred Ibis, Threskiornis aethiopicus & $0 / 10(0)$ & \\
\hline & Straw-necked Ibis, Threskiornis spinicollis & $0 / 5(0)$ & \\
\hline & White-shouldered Ibis, Pseudibis davisoni & $0 / 13(0)$ & + \\
\hline & Giant Ibis, Pseudibis gigantea & $0 / 4(0)$ & \\
\hline & Crested Ibis, Nipponia nippon & $0 / 6(0)$ & \\
\hline
\end{tabular}


Table 1. Contd....

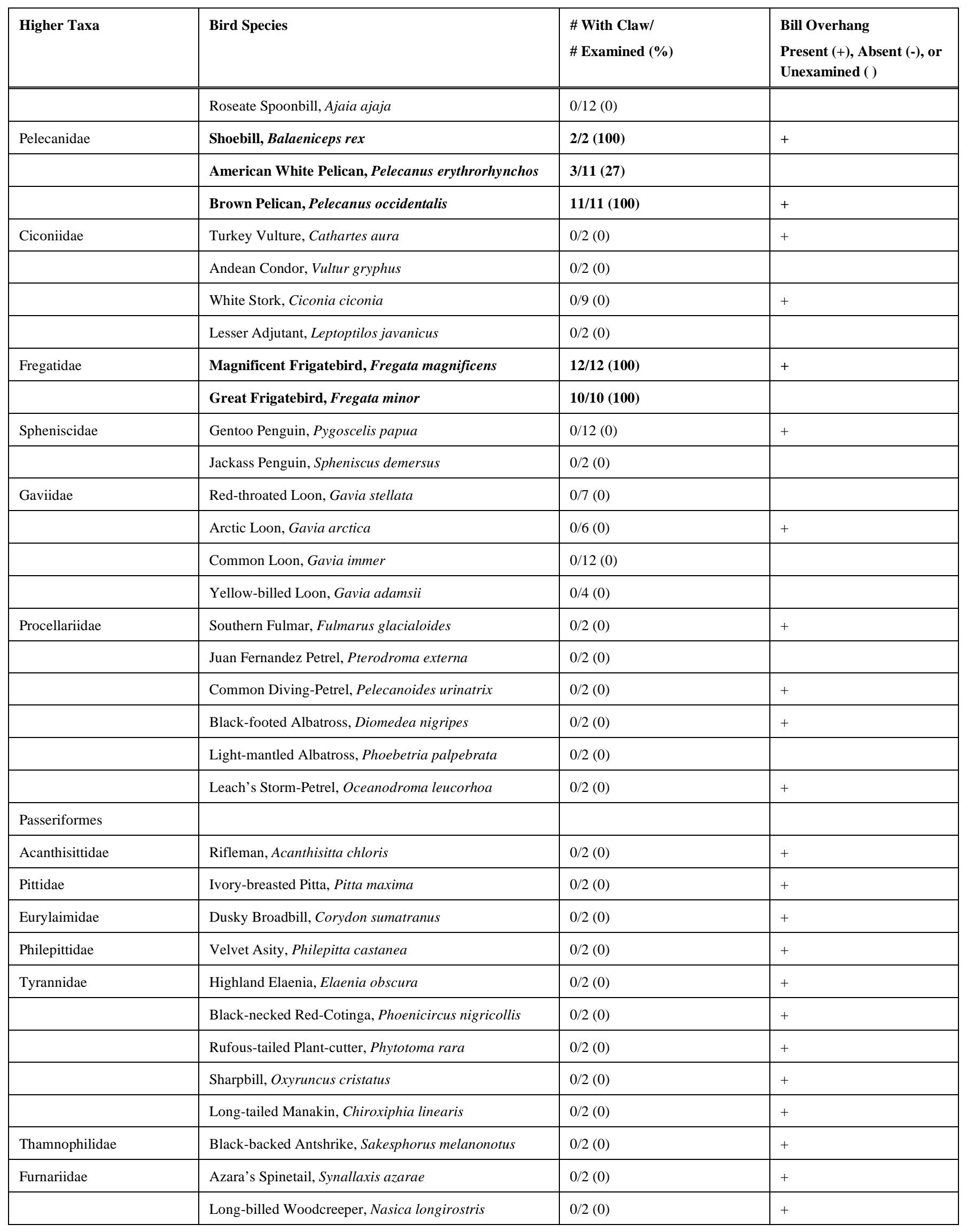


Table 1. Contd....

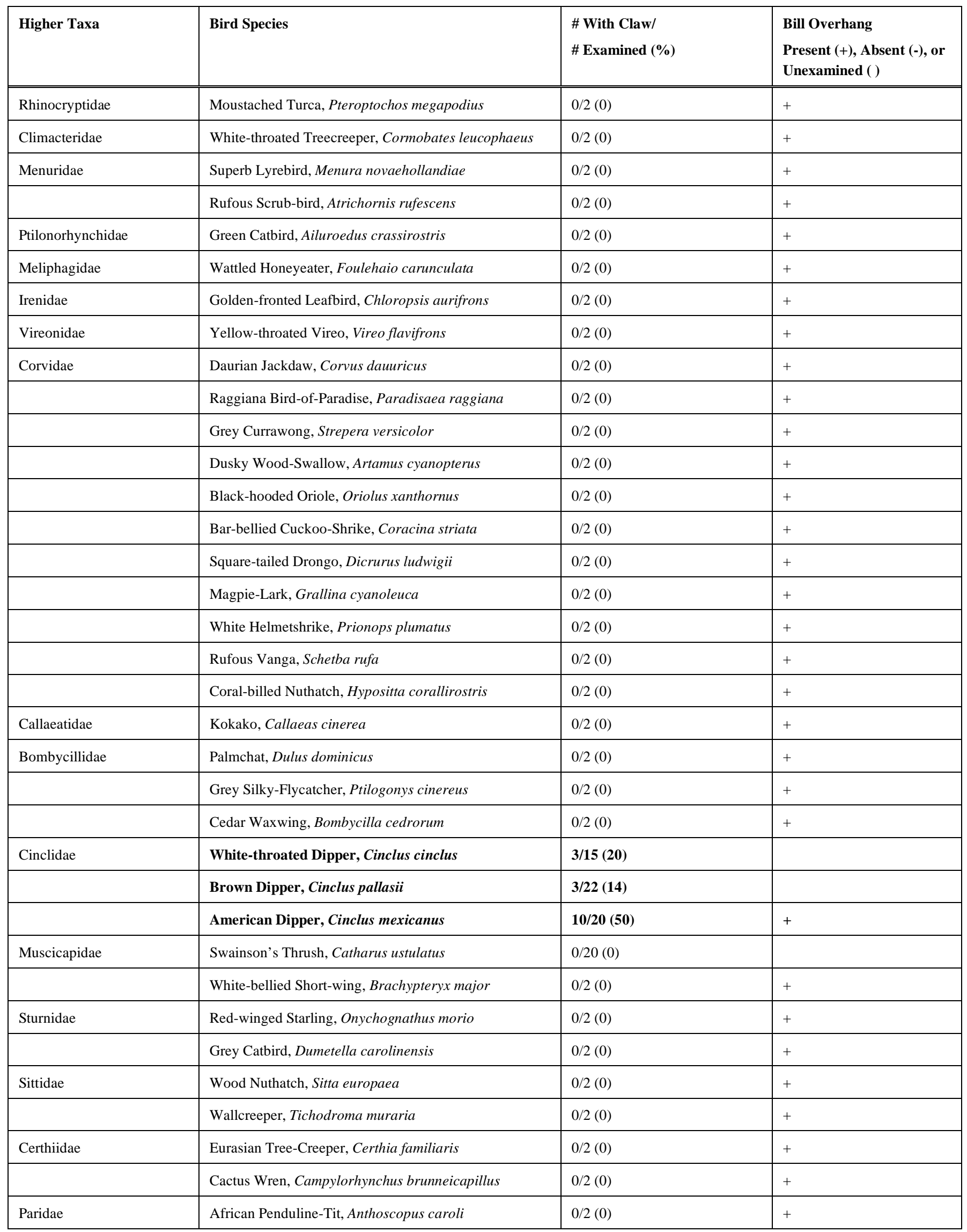


Table 1. Contd....

\begin{tabular}{|c|c|c|c|}
\hline Higher Taxa & Bird Species & $\begin{array}{l}\text { \# With Claw/ } \\
\text { \# Examined (\%) }\end{array}$ & $\begin{array}{l}\text { Bill Overhang } \\
\text { Present (+), Absent (-), or } \\
\text { Unexamined ( ) }\end{array}$ \\
\hline Aegithalidae & Bushtit, Psaltriparus minimus & $0 / 2(0)$ & + \\
\hline Hirundinidae & Caribbean Martin, Progne dominicensis & $0 / 2(0)$ & + \\
\hline Zosteropidae & White-breasted White-eye, Zosterops abyssinicus & $0 / 2(0)$ & + \\
\hline \multirow[t]{3}{*}{ Sylviidae } & Gray's Warbler, Locustella fasciolata & $0 / 2(0)$ & + \\
\hline & Ferruginous Babbler, Trichastoma bicolor & $0 / 2(0)$ & + \\
\hline & Brown Parrotbill, Paradoxornis unicolor & $0 / 2(0)$ & + \\
\hline Alaudidae & Austral-Asian Lark, Mirafra javanica & $0 / 2(0)$ & + \\
\hline \multirow[t]{2}{*}{ Nectariniidae } & Yellow-sided Flowerpecker, Dicaeum aureolimbatum & $0 / 2(0)$ & + \\
\hline & Purple-throated Sunbird, Nectarinia sperata & $0 / 2(0)$ & + \\
\hline \multirow[t]{4}{*}{ Passeridae } & Russet Sparrow, Passer rutilans & $0 / 2(0)$ & + \\
\hline & Yellow Wagtail, Motacilla flava & $0 / 2(0)$ & + \\
\hline & Alpine Accentor, Prunella collaris & $0 / 2(0)$ & + \\
\hline & White-breasted Negrofinch, Nigrita fusconota & $0 / 2(0)$ & + \\
\hline \multirow[t]{2}{*}{ Fringillidae } & Iiwi, Vestiaria coccinea & $0 / 2(0)$ & + \\
\hline & Audubon's Oriole, Icterus graduacauda & $0 / 2(0)$ & + \\
\hline
\end{tabular}

sites [154, 155]; (3) plugging parasite spiracles (breathing pores), leading to poor respiration; and (4) abrading the cuticle, leading to desiccation [132,149]. Desiccation is an intriguing possibility, given that inert dusts, such as volcanic ash, are known to kill insects by abrading their cuticles [156, 157]. Surprisingly, however, no rigorous test of this hypothesis has been conducted. Indeed, to our knowledge, no direct test of the impact of dusting behavior on ectoparasites has ever been performed. Such a study is feasible because many birds dust readily in captivity [153, 158-161]. It should be possible to "seed" parasite-free birds with identical numbers of parasites, such as feather lice, and then provide experimental birds with containers of dust. It might even be possible elicit dusting behavior in control birds by providing them a substance that is known to be harmless to ectoparasites.

\section{Sunning}

At least 50 families of birds are known to adopt stereotyped postures and expose themselves to solar radiation, which is known as "sunning" [162] (Fig. 9). Sunning is thought to control ectoparasites, either by killing them directly or by increasing their vulnerability to preening as they try to escape from the heat [163]. Sunning has intriguing parallels to "behavioral fever," which is when ectothermic animals exploit warm microclimates to combat parasites [164-166]. For example, in response to bacterial infections, Desert Iguanas (Dipsosaurus dorsalis) move to warm microclimates and generate a $2^{\circ} \mathrm{C}$ fever, which increases their survival [167]. Goldfish (Carassius auratus) increase their survival in the face of bacterial infection by frequenting warm water, which elevates their body temperature [168].

In warm environments many birds sun to the point of apparent hyperthermia [163, 169-172]. Some birds sun when it is hottest outside, not when it is coolest, suggesting that such sunning has little or nothing to do with conserving body heat. For example, Black Noddies (Anous minutus) in tropical Australia sun most frequently during periods of high temperature rather than low temperature [163], and several species of swallows sun only on hot summer days [172 - 


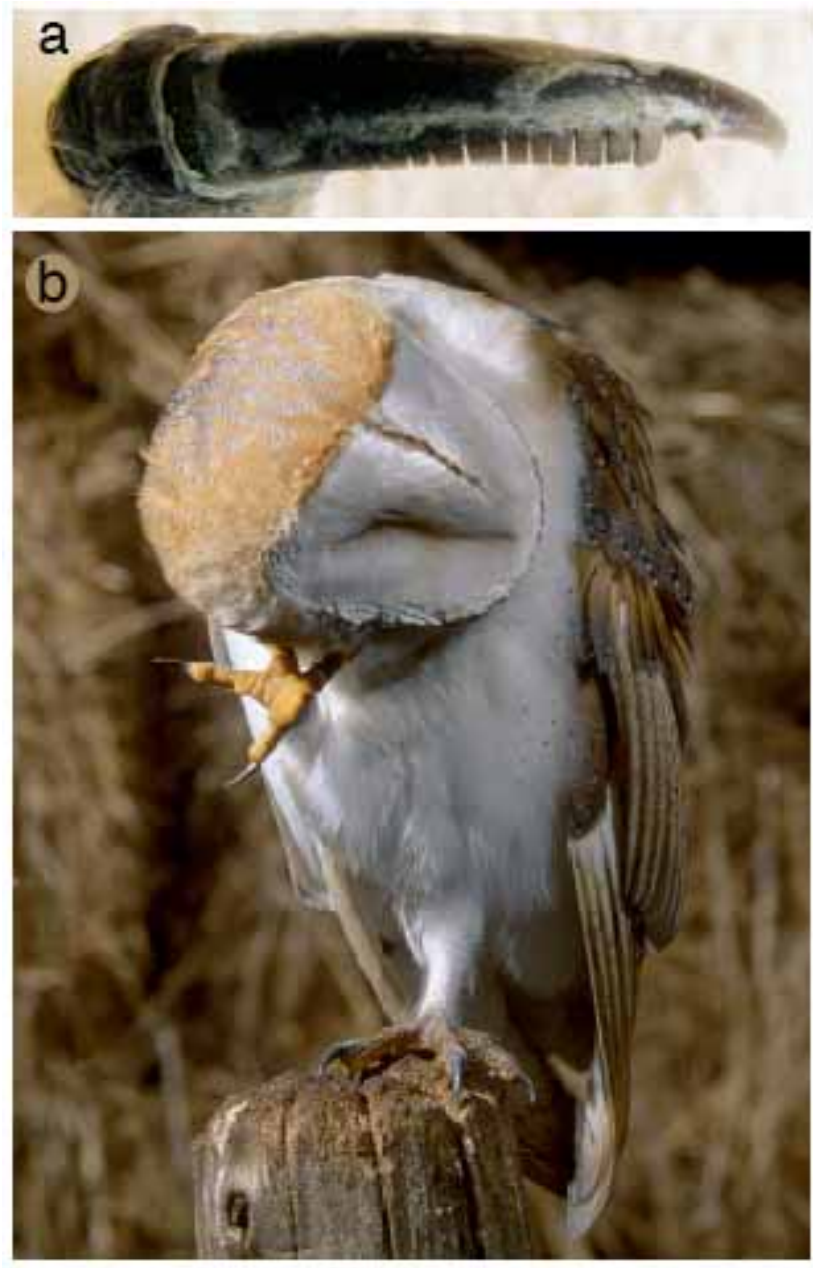

Table II. Examples of Birds Known to Dust; from Moyer and Clayton [22]

\begin{tabular}{|c|c|}
\hline STRUTHIONIFORMES & STRIGIFORMES \\
\hline STRUTHIONIDAE & STRIGIDAE \\
\hline Ostrich (Struthio) & Owl \\
\hline RHEIFORMES & CAPRIMULGIFORMES \\
\hline RHEIDAE & CAPRIMULGIDAE \\
\hline Rhea (Rhea) & Nightjar \\
\hline FALCONIFORMES & COLIIFORMES \\
\hline ACCIPITRIDAE & COLIIDAE \\
\hline Hawk & Mousebird \\
\hline FALCONIDAE & CORACIIFORMES \\
\hline Falcon & MOMOTIDAE \\
\hline GALLIFORMES & Motmot \\
\hline PHASIANIDAE & MEROPIDAE \\
\hline Grouse (Lagopus) & Bee-eater \\
\hline Bobwhite (Colinus) & CORACIIDAE \\
\hline Fowl (Gallus) & Roller \\
\hline Quail (Coturnix) & UPUPIDAE \\
\hline Partridge (Alectoris) & Hoopoe \\
\hline $\begin{array}{c}\text { Pheasant (Chrysolophus, Pha- } \\
\text { sianus) }\end{array}$ & BUCEROTIDAE \\
\hline GRUIFORMES & Hornbill \\
\hline TURNICIDAE & PASSERIFORMES \\
\hline Buttonquail & ALAUDIDAE \\
\hline CARIAMIDAE & Lark \\
\hline Seriema & TROGLODYTIDAE \\
\hline OTIDIDAE & Wren \\
\hline Bustard & TIMALIIDAE \\
\hline CHARADRIIFORMES & Wrentit (Chamaea) \\
\hline THINOCORIDAE & EMBERIZIDAE \\
\hline Seedsnipe & Sparrow (Spizella, Pooecetes) \\
\hline COLUMBIFORMES & ICTERIDAE \\
\hline COLUMBIDAE & Grackle (Quiscalus) \\
\hline Dove & PLOCEIDAE \\
\hline \multirow[t]{3}{*}{$\begin{array}{r}\text { PTEROCLIDIDAE } \\
\text { Sandgrouse }\end{array}$} & $\begin{array}{c}\text { Sparrow (Passer, Petronia, Monti- } \\
\text { fringilla) }\end{array}$ \\
\hline & GRALLINIDAE \\
\hline & Chough (Corcorax) \\
\hline
\end{tabular}

175]. Both noddies and swallows pant during these sunning episodes, indicating heat stress. 


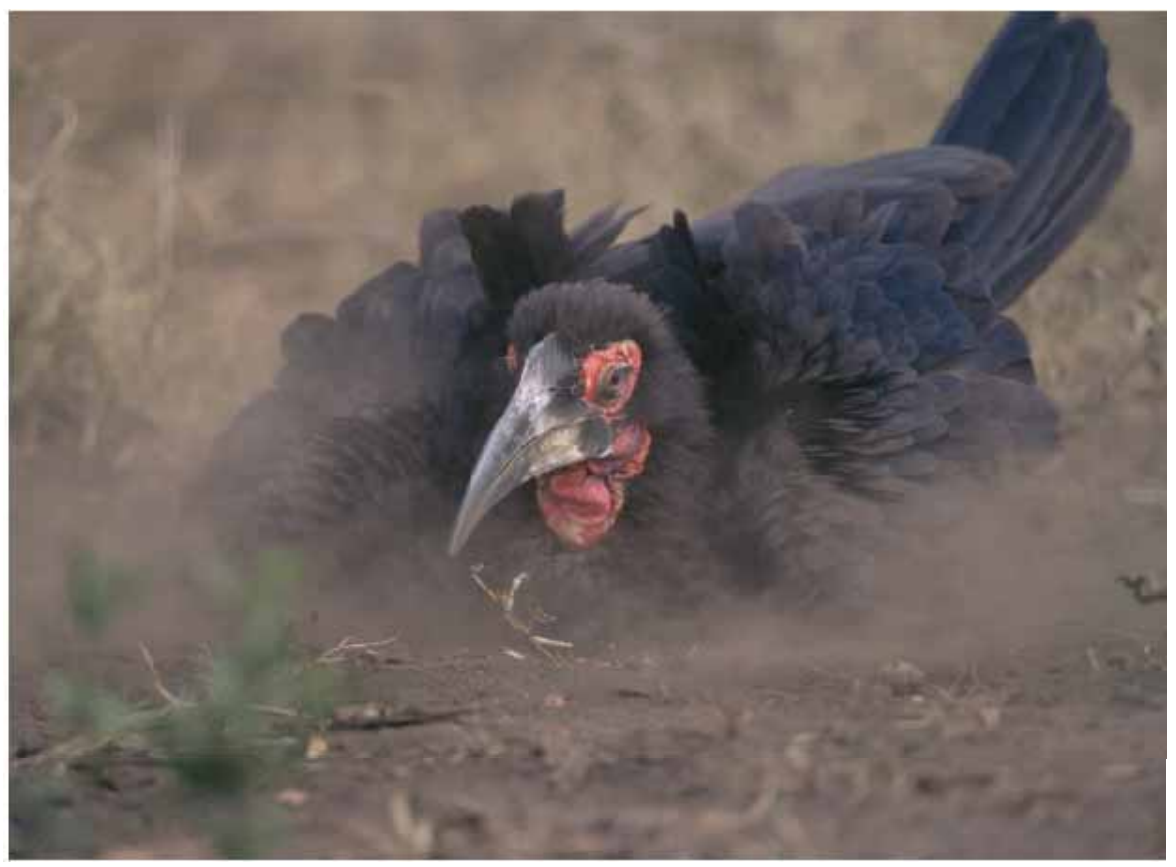

Fig. (8). Southern Ground-hornbill (Bucorvus leadbeateri) dusting itself. Photo by T. Laman (naturepl.com).

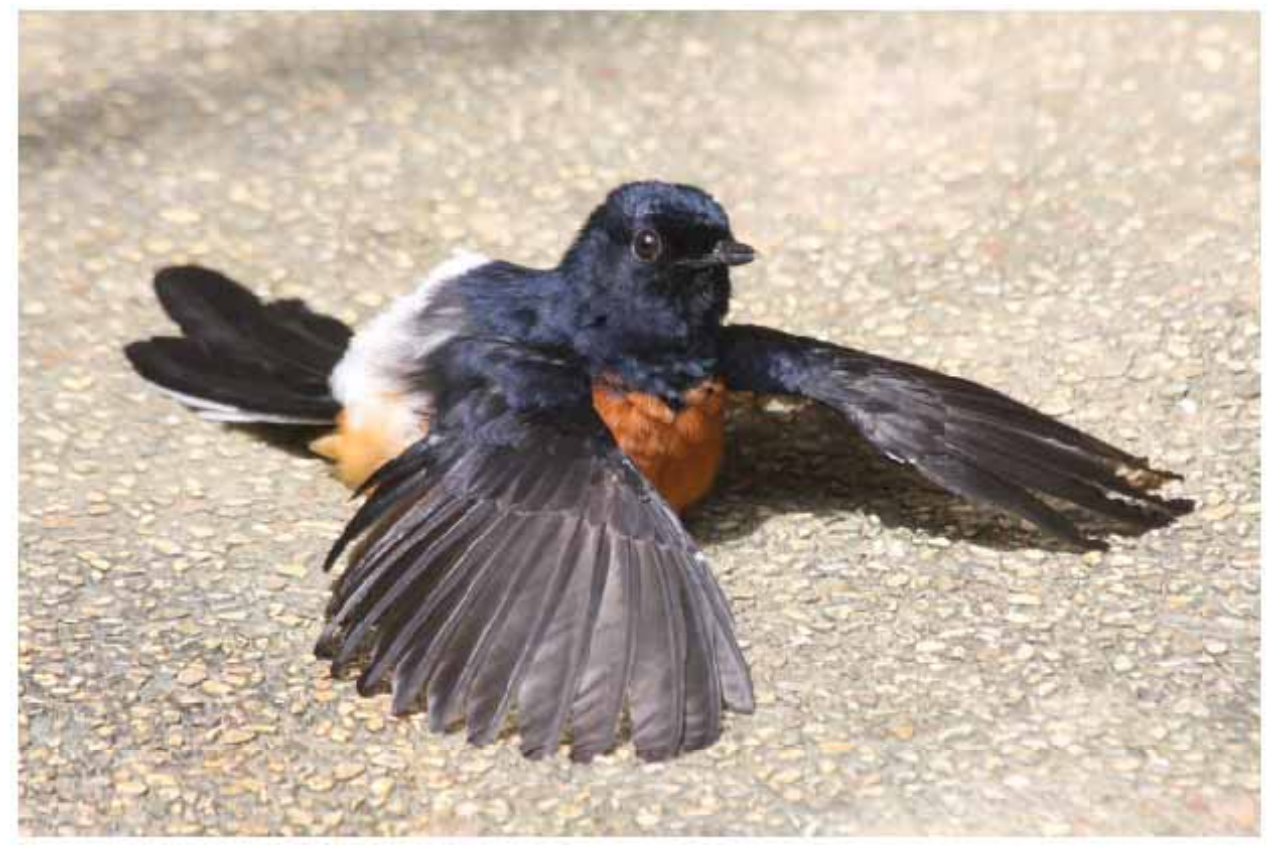

Fig. (9). White-rumped Shama (Copsychus malabaricus) sunning itself. Photo by Michael Luckett (fotolia.com).

Two lines of evidence are consistent with the hypothesis that sunning helps control ectoparasites. Blem and Blem [172] compared the rate of sunning in Violet-green Swallows (Tachycinete thalassina); experimentals were fumigated to remove ectoparasites, while controls were not. Fumigated birds sunned less frequently than controls [172], suggesting that the motivation to sun decreases with a reduction in ectoparasite load. Moyer and Wagenbach [163] exposed lice, placed on model Black Noddy wings, to sun and shade. The duration of exposure was typical of those sunning bouts, and the temperature of the model wings did not exceed that of the wings of actual sunning noddies (temperature was measured from a distance with an infrared thermometer). Significantly more lice died in the sun than in the shade.

Although this work suggests that one adaptive function of sunning is ectoparasite control, additional research is needed to determine exactly how effective sunning is for controlling different parasites, and under different conditions. For example, it would be interesting to explore whether sunning by birds with dark plumage is more effec- 
tive than sunning by birds with light plumage. Preliminary work by one of us (BRM) indicates that dark feathers heat up more rapidly, and to a higher temperature, than white feathers when exposed to the sun. Furthermore, Rock Pigeon wing lice abandon interbarb refuges of dark feathers sooner than those on white feathers when exposed sunlight. It is tempting to speculate that one cost associated with the evolution of light colored plumage might be that light colored birds have more difficulty controlling ectoparasites by sunning.

\section{Anointing}

Another hypothesized defense against ectoparasites is anointing behavior, during which birds and mammals "...apply scent-laden materials to their integument" [25]. A particularly intriguing form of anointing is "anting" behavior, during which birds crush and smear ants on their feathers (active anting), or allow ants to crawl through the plumage (passive anting) [176-181] (Fig. 10). Anting has been re- ported in over 200 bird species, most of them Passeriformes $[24,182,181]$. The fact that birds ant exclusively with ants that secrete formic acid, or other pungent fluids, suggests that anting may kill or deter ectoparasites.

Among the most compelling observations suggesting a role of anting in parasite control is Dubinin's [183] account of anting Meadow Pipits (Anthus pratensis) (cited in Kelso and Nice, [179]). Dubinin observed four pipits grasping Wood Ants (Formica rufa) in their bills and rubbing them through their plumage. He collected these birds shortly thereafter and examined them along with several other pipits that had not been seen anting. The wing feathers of the anting birds were splotched with liquid that Dubinin presumed to be formic acid. Feather mites (Pterodectes spp.) on these birds were actively moving across the feathers, and a large proportion of the mites in the moist regions of the feathers were dead. In contrast, mites on the four non-anting birds were positioned between the feather barbs and were undisturbed. More than 25\% (163 of 642) of live mites taken
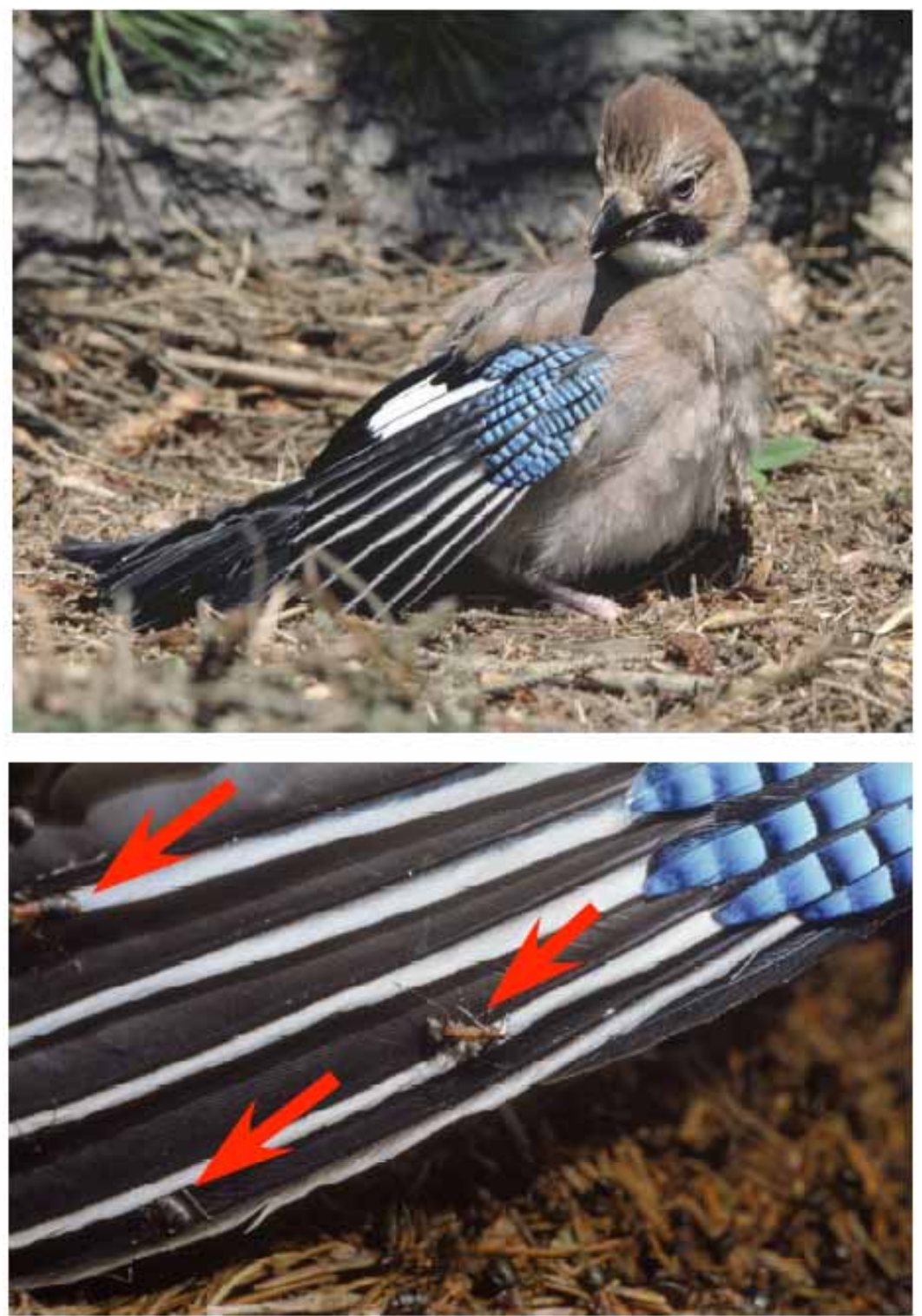

Fig. (10). Jay (Garrulus glandarius) anting. Ants (arrows) crawling on the primaries. Photos by A. Cooper (naturepl.com). 
from the anting birds died within $12 \mathrm{hr}$, compared with less than $1 \%$ (5 of 758) of those taken from the non-anting birds. Dubinin's observations are consistent with the hypothesis that anting helps control ectoparasites. However, Dubinin's work certainly does not represent a rigorous test of the hypothesis.

Clayton and Wolfe [181] provided a brief synopsis of the results of a field experiment designed to test the impact of anting by European Starlings (Sturnus vulgaris) on feather mites and lice. The experiment was conducted using 32 wildcaught birds, half of which were placed in cages $(0.8 \times 0.8 \times 0.9 \mathrm{~m})$ directly over natural Wood Ant (Formica rufa) trails, while the other half (controls) were placed in identical cages adjacent to ant trails ([184]; Bennett et al. unpublished $\mathrm{ms}$ ). The bottomless cages allowed birds direct access to ants on the ground. The lower portions of the cages were coated with Fluon ${ }^{\mathrm{TM}}$, a Teflon-coated liquid that dries to a film ants cannot cross, thus preventing them from swarming up the cage and disturbing the bird. Experimental birds (over ant trails) were observed in frequent anting behavior over the course of the field trials, which lasted three days (birds were removed from the field enclosures at night). By the end of the field trials, experimental birds had plumage that smelled strongly of formic acid. In contrast, control birds did not have access to ant trails and they seldom engaged in anting-like behavior. They did not smell of formic acid at the end of the field trials.

Ectoparasite abundance was quantified on all birds using the visual examination method [41] both the day before field trials started, and again three days after the conclusion of the field trials. The three-day interval allowed birds time to preen dead or damaged ectoparasites, while allowing parasites time to return to normal plumage microhabitats prior to the second visual census. All feather mites visible on each primary and secondary feather of each outstretched wing, as well as mites on the tail feathers, were counted with the aid of a 2x magnifying headset. All of the mites were Pteronyssoides truncates. Lice were quantified by tallying only those observed during timed visual counts of specific body regions, including the crown, face, gulum, breast, pectoral region, nape, back (60 s each), as well as the flank and rump (30 s each). Four species of lice were observed: Menacanthus eurysternus, Myrsidea cucullaris, Brueelia nebulosa, and Sturnidoecus sturni. Parasite counts were done "blind" to treatment by using Vicks ${ }^{\mathrm{TM}}$ Vaporub in the nostrils of the person doing the parasite counts. A few birds escaped or died over the course of the experiment, which left complete data sets for 25 of the 32 birds (14 experimentals and 11 controls).

Despite the fact that experimental birds anted extensively over the three day field trials, there was no significant impact of anting on mites (Fig. 11a), nor on lice (Fig. 11b). Since the post-treatment census occurred three days after the final day of formic acid exposure, there should have been ample time for any effect of acid on parasites to occur. In vitro studies show that formic acid kills more than $90 \%$ of ectoparasites within 15 minutes [177]. In addition to comparing the number of ectoparasites on birds, the condition of all of the lice was noted, as well as a haphazard sample of 25 mites on each wing of each of 14 birds (under magnification). All of the parasites appeared to be in good condition.
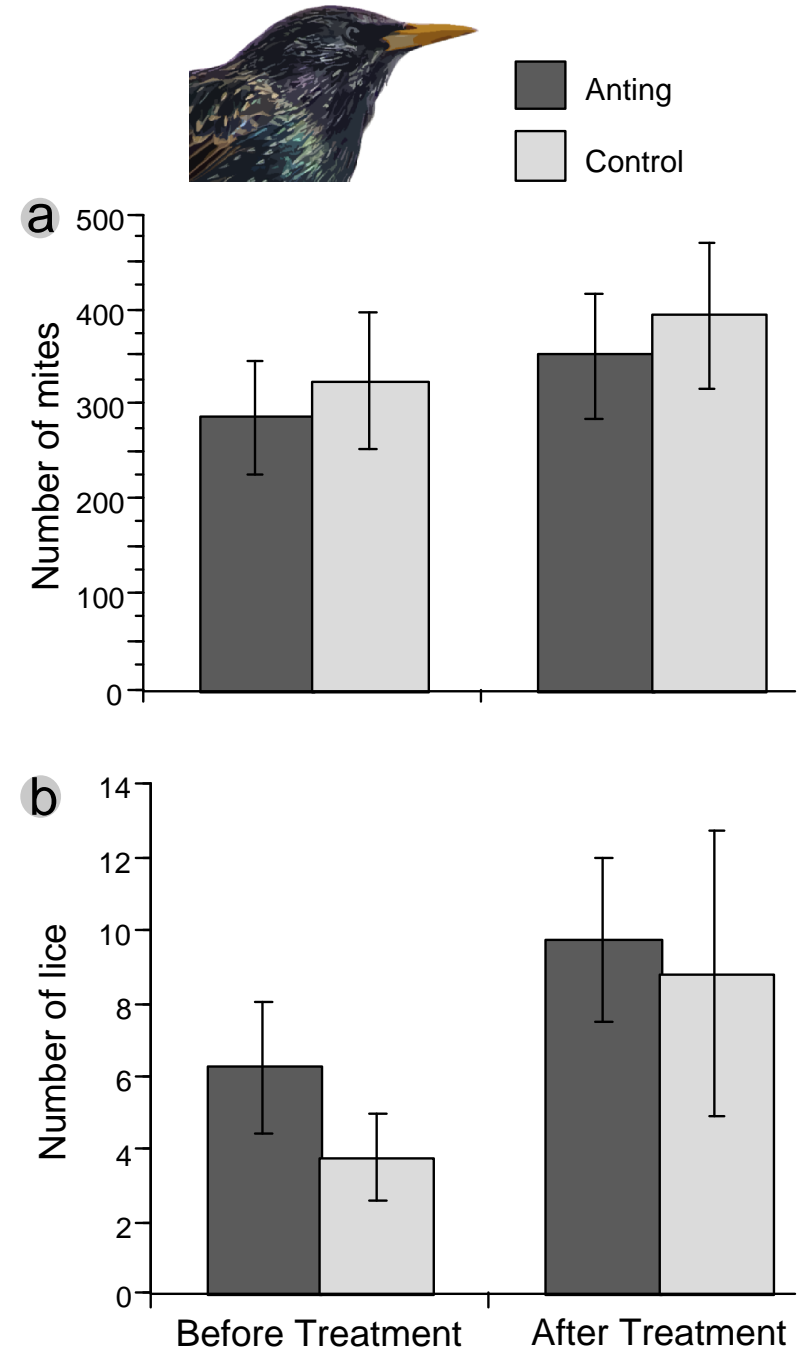

Fig. (11). Mean ( \pm SE) number of (a) feather mites and (b) lice on European Starlings (Sturnus vulgaris) before and after experimental birds were allowed to engage in anting behavior. There was no significant relationship between anting and either mite or louse loads.

These observations indicate that anting has little or no effect on mites or lice, at least on starlings. Interestingly, the number of mites and lice actually increased between the first and second visual censuses, presumably as a result of improvement on the part of the observer, and/or displacement of ectoparasites from refugia where they may have been hiding prior to the initial census and field procedures. It would be worthwhile repeating this experiment using birds that are euthanized and washed after the experiment in order to obtain more accurate estimates of total ectoparasite abundance [41].

Ehrlich et al. [185] proposed that anting behavior helps control harmful plumage bacteria or fungi. In a series of inhibition trials, Revis and Waller [186] tested polar and nonpolar ant secretions, as well as pure formic acid, for bactericidal and fungicidal effects. Although the formic acid strongly inhibited all bacteria and fungal hyphae tested, concentrations of formic acid approximating those actually found in the bodies of formicine ants did not have an effect. 
There was also no detectable effect of hexane ant-chemical extracts, nor ant suspensions in deionized water, on plumage microbes. These results suggest that anting is unlikely to control microbes. Nevertheless, an "in vivo" experiment, analogous to the one with starlings described above, is needed for a more definitive test.

Birds also anoint themselves with a bizarre list of other items, including millipedes [187, 188], caterpillars [189], garlic snails [190], bombardier beetles [191], citrus fruits [192, 193, 194], walnut juice [195], flowers [196, 197], lawn chemicals [198] and even mothballs placed in gardens to repel vegetarian pests [199-201]. Many of these items reportedly have anti-parasite properties [201], but few careful tests have been carried out.

Clayton and Vernon [194] performed one such test. The authors observed a Common Grackle (Quiscalus quiscula) anointing itself with half a lime fruit. The bird pecked at the fruit repeatedly, then preened itself while holding pieces of lime in its bill. The authors subsequently tested the effect of lime on pigeon lice in the lab. Although lime juice had no effect, exposure to vapor from the lime rind rapidly killed the lice. This result is not surprising, given that lime peel contains D-limonene, a monoterpene present at high concentrations in the peel oil of many citrus fruits, and which is known to be toxic to a wide variety of arthropods [194]. Nevertheless, the hypothesis that birds use citrus peel, or any of the other substances listed above, as a means for actually controlling their ectoparasites is still in need of in vivo testing. Experiments using parasitized captive birds engaging in anointing behavior would be informative.

\section{Cosmetic behavior}

At least 13 bird families are known to apply "cosmetic" substances to their bodies [202]. The function of this cosmetic behavior is largely unknown, but some examples suggest that the behavior may help combat ectoparasites. For example, Bearded Vultures (Gypaetus barbatus) stain their plumage with soils that are rich in iron oxide Fig. (12), [203, 204]. They either rub their plumage in dry red soil, or rub damp red soil into their plumage following a bath. Vultures spend as much as an hour applying the soil [204]. Captive Bearded Vultures return to their nests following episodes of soil bathing and rub their newly stained feathers on eggs and offspring [205]. Frey and Roth-Callies [203] [cited in Negro et al. [204]] tested for an effect of iron oxide on lice, but there was no significant difference in the survival of lice exposed to a suspension containing iron oxide vs. water controls. Arlettaz et al. [205] argued that, since Bearded Vultures are often the last species to feed upon carcasses, they may also be exposed to dangerous quantities of bacteria left behind by earlier scavengers. The oxidative properties in iron oxide rich soils may reduce the negative effects of such bacteria on egg development and nestling growth [205]. However, experimental tests are needed to investigate the effects of iron oxides on bacterial strains.

In a recent review of cosmetic coloration, Delhey and colleagues [202] describe two other kinds of cosmetic behavior that might deter ectoparasites. Shortly before breeding, the Japanese Crested Ibis (Nipponia nippon) secretes a black substance from the skin of its head and neck, which is then preened into the plumage [206]; whether this substance has

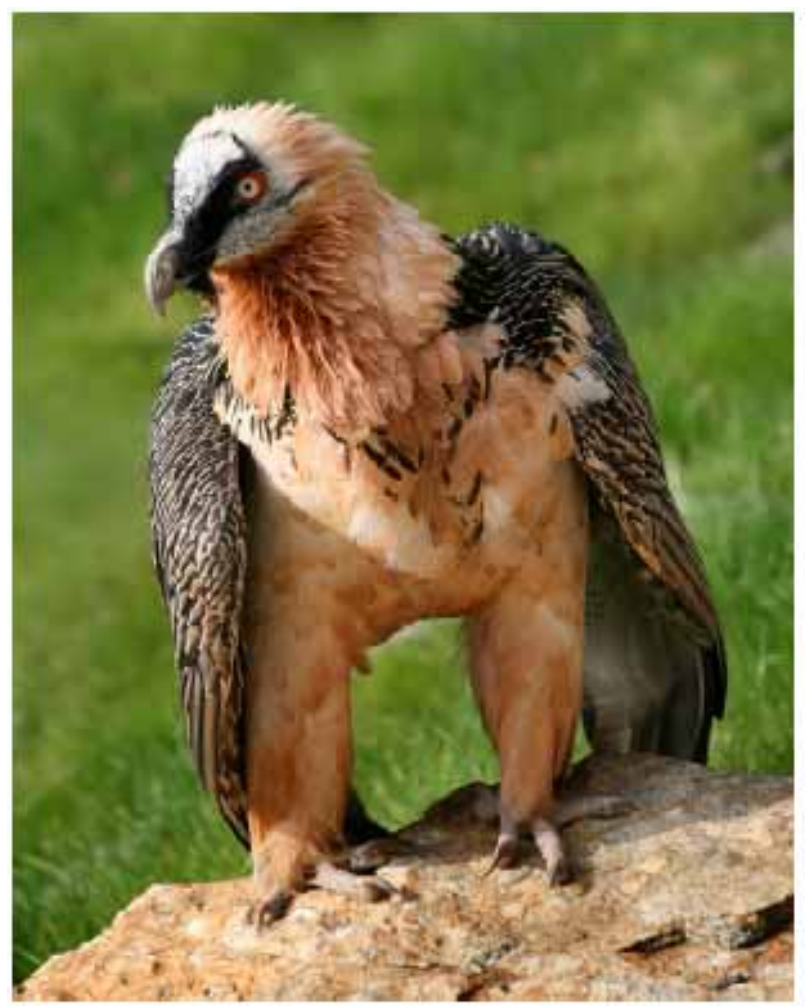

Fig. (12). Bearded vultures (Gypaetus barbatus) stain their plumage with soil rich in iron oxide; captive birds without access to such soil have white underparts. Photo by Richard Bartz (commons.wikimedia.org).

any effect on ectoparasites has not been tested. Other species of birds, such as Cinnamon Bitterns (Ixobrychus cinnamomeus) and Night Herons (Nycticorax nycticorax), apply powder down - specialized feathers that degrade into a powder - to their head and neck regions [207, 208]. The powder down alters the color of these regions, suggesting an intraspecific signaling function. However, since these are also the areas that the bird cannot reach with its bill to preen, it is conceivable that the application of substances to these regions could also help deter parasites. No test of this hypothesis has been conducted.

\section{NEST MAINTENANCE BEHAVIOR}

In addition to combating ectoparasites on their bodies, birds must defend themselves from parasites in their nests. Parasites such as fleas, flies, true bugs, and some mites spend portions of their life cycle in the nest material and make brief forays onto nestlings and parents to feed [5]. It is not uncommon for such parasites to kill nestlings or fledglings [45, 209]. Birds have several kinds of nest maintenance behavior that may deter ectoparasites.

\section{Territoriality and Colony Size}

Parasite transmission is often more efficient in dense host populations [210]. For this reason, antisocial behavior, such as territoriality, may provide benefits in terms of defense against ectoparasites [211]. Similarly, in colonial species, nesting in smaller colonies can help control ectoparasites because parasite load is proportional to colony size [212]. 


\section{Nest Site Avoidance}

The most effective defense against nest parasites may be to simply avoid them in the first place. A number of studies have shown that birds can detect and avoid nesting (and roosting) sites containing ectoparasites [24, 212-221]. For example, Oppliger et al. [214] experimentally investigated the effects of the hematophagous Hen Flea (Ceratophyllus gallinae) on nest-site choice in the Great Tit (Parus major). When offered a choice between adjacent nest boxes, one flea-infested and one flea-free, significantly more Great Tits chose parasite-free boxes.

Cliff Swallows (Hirundo pyrrhonota) show a similar preference for uninfested nests. Brown and Brown [212] noted that during the early spring, overwintering fleas (Ceratophyllus celsus) and Swallow Bugs (Oeciacus vicarius) congregate in plain view at the entrances of old swallow nests. This location is a good position from which to infest swallows that enter the nest, or even swallows that come too close to inspect the nest opening, allowing the fleas to leap onto such birds. When they return from the wintering grounds, Cliff Swallows often hover a few centimeters in front of old nests, rather than entering them. This behavior appears to allow the birds to safely inspect the nest opening for ectoparasites [212].

Another way in which birds can avoid ectoparasites is by choosing to breed when fewer ectoparasites are present at nest sites. For example, Great Tits delay reproduction to minimize infestations by Hen Fleas [222], which - like swallow fleas - overwinter in the nest cavity. If a host does not use the cavity, the fleas emigrate [223]. Hence, by delaying reproduction, birds can reduce exposure to fleas. In an experimental test of this delayed-reproduction hypothesis, Oppliger et al. [214] found that Great Tits whose nest boxes were infested with fleas started laying eggs 11 days later than birds occupying uninfested nest boxes.

\section{Nest Sanitation}

In some cases, birds are known to engage in nest "sanitation" behavior [24]. Female Great Tits and Blue Tits (Parus caeruleus) exhibit this behavior, which Christe et al. [224] described as "a period of active search with the head dug into the nest material." It is unclear whether this kills or simply disperses ectoparasites, but female Great Tits devote significantly more time to sanitation in flea-infested nests than in uninfested nests [224]. Similarly, female Blue Tits spend more time in sanitation of nests infested with blowfly (Protocalliphora) larvae [225] or fleas [226] than in uninfested nests [225]. Another form of nest sanitation is to clean out nests that have been used before; for example, male House Wrens (Troglodytes aedon) remove old nest material from their nest boxes prior to each reproductive bout. Pacejka et al. [227] showed that this behavior effectively reduces the abundance of mites (Dermanyssus) in the nest.

\section{Nest Fumigation}

An interesting purported adaptation for controlling ectoparasites in nests is the use of aromatic vegetation to fumigate the nest [24, 25, 73, 181, 228]. Clark and Mason [229] showed that European Starlings (Sturnus vulgaris) select species of plants that contain volatile chemicals with antibac- terial and insecticidal properties. The authors found that the hatching success of lice (Menacanthus sp.) and the growth of several strains of bacteria (Streptococcus aurealis, Staphylococcus epidermis, and Pseudomonas aeruginosa) were significantly reduced when exposed to volatiles from plants preferred by starlings, compared to a random sample of nearby vegetation. A subsequent study showed that emergence of a mite (Ornithonyssus sylviarum) was significantly decreased when wild carrot (Daucus carota) or fleabane (Erigeron philadelphicus) was added to the nesting material [230].

A recent study of Bonelli's Eagles (Hieraaetus fasciatus) showed that nests with higher percentages of pine greenery had fewer blow fly larvae (Protocalliphora) and higher host breeding success [231]. The results of this observational study are intriguing, but they have not yet been tested by experimental manipulation. In another study, which did use an experimental approach, Shutler and Campbell [232], added yarrow (Achillea millefolium) to the nests of Tree Swallows (Tachycineta bicolor); this manipulation reduced the number of fleas in the nest by half, compared to control nests. However, the authors did not find that the use of green vegetation and the subsequent reduction in fleas had any effect on nestling survival or fledgling success. Gwinner et al. [233] manipulated green vegetation in European Starling (Sturnus vulgaris) nests and found no difference in the number of ectoparasites (mites, lice, fleas) between experimental and control nests; however, nestlings from nests with vegetation did have higher red blood cell counts and body masses than nestlings from nests without vegetation. The authors argued that the vegetation may stimulate the immune system of nestlings, which could ameliorate the detrimental effects of blood-feeding ectoparasites, even though it did not change parasite number, per se. This hypothesis has not been tested.

Yet another recent study, this one with Blue Tits (Cyanistes caeruleus), showed that in enlarged broods, nestling mass gain was positively affected by the addition of green vegetation [234]. However, there was no difference in fledgling body mass between chicks in nests with added vegetation versus control nests. In conclusion, these various studies reveal a link between green vegetation and decreased ectoparasite loads, and a link between vegetation and increased nestling condition. However, there is still no rigorous experimental evidence that fumigation of nests with green vegetation actually increases the fitness of birds by deterring parasites.

\section{Heterospecific Cleaning}

Birds can conceivably reduce ectoparasites using what Hart [24] referred to as "heterospecific cleaning". Both of the known cases involve nest maintenance. The most remarkable example was reported in a paper by Smith [235]. He observed that brood parasitic Giant Cowbirds (Scaphidura oryzivora) are tolerated by some nesting colonies of foster species, such as Yellow-rumped Caciques (Cacicus cela) and oropendolas (Psarocolius wagleri, P. decumanus, Gymnostinops montezuma). Smith [235] reported that the cost of brood parasitism was offset by the fact that the nestling cowbirds remove and consume parasitic botflies (Philornis) from the foster parents' offspring, thus enhancing the fledging success of the foster species. Selection for cowbird egg mim- 
icry was relaxed under these conditions, explaining a higher frequency of non-mimetic eggs in colonies parasitized by flies. This "advantage of being parasitized" (by cowbirds) was reportedly lost in the case of cacique or oropendola colonies adjacent to large wasp nests, because the wasps deterred the flies from parasitizing bird nests. In such cases, cowbirds were not tolerated by the foster species and the frequency of mimetic eggs was higher. These interactions, which are among the most complex ever documented, need additional study and confirmation.

Gehlbach and Baldridge [236] reported another form of heterospecific cleaning. They documented higher growth rates of nestling Eastern Screech Owls (Otus asio) in nests with Blind Snakes (Leptotyphlops dulcis). Superficial scars on the snakes suggested they were transported to the nest by adult owls, yet not eaten. The authors argued that growth rates of young in nests containing snakes were higher because the snakes fed on parasitic larvae that are harmful to the nestlings. However, other factors could covary with snake presence and owlet growth, e.g., parental hunting ability. An experimental manipulation of snake presence is needed to test Gehlbach and Baldridge's [236] hypothesis.

Cleaning of one species of bird by another species, analogous to the cleaning symbioses of marine fishes, has also been suggested. Bowman and Billeb [237] speculated that the bizarre feeding behavior of "vampire" Sharp-beaked Ground Finches (Geospiza difficilis), which puncture the pin-feathers of boobies to feed upon their blood, may have originated from finches feeding on the large, numerous hippoboscid flies that plague the boobies. This is an intriguing idea, but the authors were quick to point out that they did not actually observe finches feeding on hippoboscid flies. We are unaware of any other documented cases of cleaning interactions between different species of birds.

\section{Nest Desertion}

If all else fails, an ultimate strategy for dealing with nest parasites is simply to abandon the nest, rather than continuing to invest in offspring that may be doomed. Nest desertion in the face of high ectoparasite loads has been documented for many bird species [45, 212, 214, 238-245]. Duffy [242] showed that argasid ticks (Ornithodoros amblus) cause large-scale desertion of colonial seabird nesting colonies, which raises interesting questions. How often do adult birds desert because they are cutting their losses, versus simply escaping intolerable irritation? Because short-lived birds have fewer breeding seasons in which to reproduce, shortlived birds should be slower to abandon their nests than long-lived birds, all else being equal. Comparative and experimental studies are needed to investigate how life span affects the decision to desert nests, in the face of high ectoparasite load.

\section{DISCUSSION}

As we have tried to show, birds have an impressive array of possible defenses against ectoparasites. Different species of birds may use very different combinations of these defenses, but the extent to which this actually occurs is not known. Most work has focused on demonstrating what the various defenses are, and, in some cases, exactly how they function. A more complete understanding of how birds com- bat ectoparasites requires a broader perspective that considers how the different defenses interact, and the relationship of ectoparasite defense to the many other life history challenges birds face. The optimum strategy undoubtedly depends on various life history tradeoffs. Multiple defenses and how they interact are also important to document in order to better understand the nature of coevolutionary responses to host defense by the parasites themselves. The evolution of effective counterstrategies should be more difficult, all else being equal, if a host has more than one effective defense strategy.

Environmental constraints will also limit the defenses available to different species. Opportunities for sunning are more limited for birds that live in regions with an average of 300 days per year of rain (e.g., Seattle, Washington), compared to regions with an average of 300 days/year of sun (e.g., Salt Lake City, Utah). Redundant defenses may also be important in the face of environmental variability. Sunning and dusting may combat similar ectoparasites, but dusting is an option on a cloudy day, while sunning may be effective in habitats devoid of dust or loose dirt.

Composition of the ectoparasite community will also influence the defenses used by a given host. Ectoparasite species richness and abundance vary markedly among birds, even within single groups of ectoparasites [124]. Some species of tinamous (Tinamiidae) can be infested with a dozen species of lice, while ostriches (Struthionidae) have but one species [5, 63]. Defense strategies against a single species probably differ from those against a more diverse community. Consistent with this prediction, bird species known to host more species of lice appear to devote more time to maintenance behavior than birds with few species of lice [246]. This kind of relationship probably holds for other kinds of ectoparasites, as well.

Ectoparasite species richness can also vary within a single bird species. Brown and Wilson [247] compared the ectoparasite communities of House Sparrows in Europe and North America. They found that 34 of the 69 species of ectoparasites found on the European sparrows were "lost" when House Sparrows were introduced to North America. It would be interesting to test whether North American sparrows have lost certain defenses as a result of the reduction in the richness of their ectoparasite community.

Ectoparasite prevalence also varies across environments. A worldwide comparison of louse prevalence among 22 species of pigeons and doves (Columbidae) revealed a positive relationship between louse prevalence and ambient humidity [22]. For example, lice were found on fewer than $3 \%$ of birds in the Sonoran Desert of Arizona, whereas 92\% and $100 \%$ of birds in Philippine and Peruvian rainforests, respectively, were infested. Moyer et al. [37] showed that pigeons and doves in arid habitats also have lower louse abundance than conspecifics in humid habitats. To confirm humidity as the causal agent, the authors experimentally manipulated the ambient humidity of captive feral Rock Pigeons. Louse infestations decreased greatly on birds kept at low humidity, compared with those at higher humidities.

The "arsenal" of defenses employed by a given bird species will also depend on adaptations that are not immediately 
related to parasite control. Ornithologists have traditionally interpreted bill shape mainly as it relates to foraging [126, 248-250]. However, recent studies (e.g. Clayton et al. [125]; Fig. 4) make it clear that selection for efficient preening can also play a role in the evolution of bill morphology. In environments with high ectoparasite pressure, selection for preening-efficient bills may be strong. Some species of birds have foraging ecology that precludes a maxillary overhang (e.g. woodpeckers, hummingbirds, oystercatchers (Fig. 2b), skimmers, darters, and herons; Table I). These taxa are presumably under selective pressure to evolve other mechanisms for controlling ectoparasites.

Finally, ectoparasite defense may also vary in terms of investment in particular defenses, independent of other defenses. For example, preening birds cannot simultaneously forage or engage in courtship. Preening also reduces vigilance [251], increasing the risk of predation. Given these costs of preening, we predict that birds in areas of low ectoparasite pressure should spend less time preening than birds in areas of high ectoparasite pressure. This hypothesis would be easy to test simply by comparing preening rates of birds in different localities (e.g., Clayton and Cotgreave [105]). We expect that tradeoffs of this kind may be common for many of the different adaptations birds have for controlling ectoparasites.

\section{CONCLUSION}

Birds have a wide variety of defenses for combating their diverse communities of ectoparasites. In some cases there is overwhelming evidence that a particular trait is important in ectoparasite defense (e.g., preening). In other cases the purported defense has not been tested (e.g, dusting). In still other cases, recent evidence suggests that the purported defense may, in fact, have little to do with ectoparasite control (e.g. pectinate claws). Multiple defenses allow birds to target different types of ectoparasites and to defend themselves in the face of environmental variability. Birds should also modulate the use of particular defenses, as well as combinations of defenses, in response to the many life history demands they face.

\section{ACKNOWLEDGMENTS}

We thank Aldo Poiani for inviting us to contribute to this volume. We thank A. Smith, P. Angle, D. Brewer, E. Burtt, P. Coley, M. Cottam, H. Douglas, J. Dean, K. Johnson, A. Møller, R. Moyle, S. Nelson, N. Newbold, D. Reed, M. Robbins, A. Rock, A. Smith, J. Weckstein and an anonymous referee for assistance and/or advice regarding different aspects of this review. We are grateful to J. Belthoff and T. Boves for access to Barn Owl specimens, and to J. Lokvam for help interpreting chemical ecology data. The Division of Birds of the National Museum of Natural History allowed us access to their skin collection. We are grateful to R. Price for tallying louse species richness for the pectinate claw analysis. We are grateful to A. Farley for assistance preparing the manuscript. This work was supported by grants from Sigma $\mathrm{Xi}$, the Frank M. Chapman Memorial Fund, and the National Science Foundation (DEB-9703003, NSF DEB-0344430, DEB-0743491, and DEB-0816877 to DHC).

\section{SUPPLEMENTARY MATERIAL}

Supplementary material is available on the publishers Web site along with the published article.

\section{REFERENCES}

[1] Owen JP, Delany ME, Cardona CJ, Bickford AA, Mullens BA. Host inflammatory response governs fitness in an avian ectoparasite, the northern fowl mite (ornithonyssus sylviarum). Int J Parasitol 2009; 39: 789-99.

[2] Wikel SK, Ed. The immunology of host-ectoparasitic arthropod relationships. Wallingford UK: CAB International 1996.

[3] Owen JP, Nelson AC, Clayton DH. Ecoimmunity of birdectoparasite systems. Trends Parasitol 2010; [in press].

[4] Rothschild M, Clay T. Fleas, flukes and cuckoos. London: Collins 1952.

[5] Marshall AG. The ecology of ectoparasitic insects. London: Academic Press 1981.

[6] Janovy J. Protozoa, helminths, and arthropods of birds. In: Clayton DH, Moore J, Eds. Host-parasite evolution: general principles and avian models. New York: Oxford Univ Press 1997; pp. 303-37.

[7] Walter DE, Proctor HC. Mites: ecology, evolution, and behaviour. New York: CABI Publishing 1999.

[8] Proctor H, Owens I. Mites and birds: diversity, parasitism and coevolution. Trends Ecol Evol 2000; 15: 358-64.

[9] Proctor HC. Feather mites (Acari: Astigmata): ecology, behavior, and evolution. Annu Rev Entomol 2003; 48: 185-209.

[10] Davies RW, Govedich FR, Moser WE. Leech parasites of birds. In: Atkinson CT, Thomas NJ, Hunter DB, Eds. Parasitic diseases of wild birds. Iowa: Wiley-Blackwell 2008; pp. 501-14.

[11] Pugh GJF. The contamination of birds' feathers by fungi. Ibis 1972; 114: 172-7.

[12] Gunderson AR. Feather-degrading bacteria: a new frontier in avian and host-parasite research? Auk 2008; 125: 972-9.

[13] Hamilton WD, Zuk M. Heritable true fitness and bright birds: a role for parasites? Science 1982; 218: 384-7.

[14] Møller AP, Allander K, Dufva R. Fitness effects of parasites on passerine birds: a review. In: Blondel J, Gosler A, Lebreton J, McCleery RH, Eds. Population biology of passerine birds. Berlin: Springer-Verlag 1990; pp. 269-80.

[15] Loye JE, Zuk M, Eds. Bird-parasite interactions: Ecology Evolution and Behavour. Oxford: Oxford Univ Press, UK 1991.

[16] Lehmann T. Ectoparasites: direct impact on host fitness. Parasitol Today 1993; 9: 8-13.

[17] Andersson M. Sexual selection. Princeton: Princeton Univ Press 1994.

[18] Clayton DH, Moore J, Eds. Host-parasite evolution: general principles and avian models. Oxford: Oxford Univ Press 1997.

[19] Hillgarth N, Wingfield JC. Parasite-mediated sexual selection: endocrine aspects. In: Clayton DH, Moore J, Eds. Host-parasite evolution: general principles and avian models. New York: Oxford Univ Press 1997; pp. 78-104.

[20] Møller AP, Christe P, Lux E. Parasitism, host immune function and sexual selection. Q Rev Biol 1999; 74: 3-20.

[21] Atkinson CT, Thomas NJ, Hunter DB, Eds. Parasitic diseases of wild birds. Iowa: Wiley-Blackwell 2008.

[22] Moyer BR, Clayton DH. Avian defenses against ectoparasites. In: van Emden HF, Rothschild M, Eds. Andover, U.K: Intercept Ltd. Insect and Bird Interact 2004; pp. 241-57.

[23] Lehane MJ. Biology of blood sucking insects. London: Harper Collins Academic 1991.

[24] Hart BL. Behavioural defence. In: Clayton DH, Moore J, Eds. Host-parasite evolution: general principles and avian models. New York: Oxford Univ Press 1997; pp. 59-77.

[25] Weldon PJ, Carroll JF. Vertebrate chemical defense: secreted and topically acquired deterrents of arthropods. In: Debboun M, Frances SP, Stickman D, Eds. Insect repellents: principles, methods and uses. New York: CRC Press 2006; pp. 47-75.

[26] Bush AO, Lafferty KD, Lotz JM, Shostak AW. Parasitology meets ecology on its own terms: Margolis et al. revisited. J Parasitol 1997; 83: 575-83.

[27] Fukatsu T, Koga R, Smith WA, et al. Bacterial endosymbiont of the slender pigeon louse Columbicola columbae allied to endosym- 
bionts of grain weevils and tsetse flies. Appl Environ Microbiol 2007; 73: 6660-8.

[28] Strong DR, Jr, Lawton JH, Southwood TRE. Insects on plants: community patterns and mechanisms. Oxford: Blackwell Scientific Publications 1984

[29] Stiling P, Simberloff D, Brodbeck BV. Variation in rates of leaf abscission between plants may affect the distribution patterns of sessile insects. Oecologia 1991; 88: 367-70.

[30] Burtt EH, Ichida JM. Occurrence of feather-degrading bacilli in the plumage of birds. Auk 1999; 116: 364-72.

[31] Ash JS. A study of the Mallophaga of birds with particular reference to their ecology. Ibis 1960; 102: 93-110.

[32] Post W, Enders F. The occurrence of Mallophaga on two bird species occupying the same habitat. Ibis 1970; 112: 539-40.

[33] Blagoveshchensky DI. Mallophaga. Part 1. Introduction (English translation). Nasekomye pukhoedy, Fauna SSSR ns 1959; 1: pp. 1202.

[34] Baum H. Biology and ecology of the feather lice of blackbirds (In German). Angew Parasitol 1968; 9: 129-75.

[35] Markov GC. Seasonal and annual variations in parasito-fauna of starlings in connection with changes in meteorological factors. Zool Zhurnal 1940; 19: 741-9.

[36] Boyd EM. A survey of parasitism of the starling Sturnus vulgaris L. in North America. J Parasitol 1951; 37: 56-84.

[37] Moyer BR, Drown DM, Clayton DH. Low humidity reduces ectoparasite pressure: Implications for host life history evolution. Oikos 2002; 97: 223-28.

[38] Bush SE, Harbison CW, Slager DL, Peterson AT, Price RD, Clayton DH. Geographic variation in the community structure of lice on Western Scrub-Jays. J Parasitol 2009; 95: 10-3.

[39] Hamstra TL, Badyaev AV. Comprehensive investigation of ectoparasite community and abundance across life history stages of avian host. J Zool 2009; 278: 91-99.

[40] Moyer BR, Gardiner DW, Clayton DH. Impact of feather molt on ectoparasites: looks can be deceiving. Oecologia 2002; 131: 20310.

[41] Clayton DH, Drown DM. Critical evaluation of five methods for quantifying chewing lice (Insecta: phthiraptera). J Parasitol 2001; 87: 1291-300.

[42] Chandra S, Agarwal GP, Singh SPN, Saxena AK. Seasonal changes in a population of Menacanthus eurysternus (Mallophaga, Amblycera) on the common myna Acridotheres tristi. Int J Parasitol 1990; 20: 1063-65.

[43] McGroarty DL, Dobson RC. Ectoparasite populations on house sparrows in northwestern indiana, Am Midl Nat 1974; 91: 479-86.

[44] Eveleigh ES, Threlfall W. Population dynamics of lice (Mallophaga) on auks (Alcidae) from newfoundland. Can J Zool 1976; 54: 1694-711.

[45] Clayton DH, Tompkins DM. Ectoparasite virulence is linked to mode of transmission. Proc R Soc Lond B Biol Sci 1994; 256: 21117.

[46] Lee PLM, Clayton DH. Population biology of swift (Apus Apus) ectoparasites in relation to host reproductive success. Ecol Entomol 1995; 20: 43-50.

[47] Harbison CW, Bush SE, Malenke JR, Clayton DH. Comparative transmission dynamics of competing parasite species. Ecology 2008; 89: 3186-94.

[48] Foster MS. Synchronised life cycles in the orange-crowned warbler and its mallophagan parasites. Ecology 1969; 50: 315-23.

[49] Schieltz PC, Murphy ME. The contribution of insulation changes to the energy cost of avian molt. Can J Zool 1997; 75: 396-400.

[50] Swaddle JP, Witter MS. The effects of molt on the flight performance, body mass, and behavior of European starlings (Sturnus vulgaris): an experimental approach. Can J Zool 1997; 75: 1135-46.

[51] Lindström A, Visser GH, Daan S. The energetic cost of feather synthesis is proportional to basal metabolic rate. Physiol Zool 1993; 66: 490-510.

[52] Dawson A, Hinsley SA, Ferns PN, Bonser RHC, Eccleston L. Rate of moult affects feather quality: a mechanism linking current reproductive effort to future survival. Proc R Soc Lond B Biol Sci 2000; 267: 2093-98

[53] Jovani R, Serrano D. Feather mites (Astigmata) avoid moulting wing feathers of passerine birds. Anim Behav 2001; 62: 723-27.

[54] Casto SD. Entry and exit of syringophilid mites (Acarina: Syringophilidae) from the lumen of the quill. Wilson Bull 1974; 86: $272-78$.
[55] Kethley J. Population regulation in quill mites (Acarina: Syringophilidae). Ecology 1971; 52: 1113-18.

[56] Jovani R, Serrano D, Frias O, Blanco G. Shift in feather mite distribution during the molt of passerines: the case of barn swallows (Hirundo rustica). Can J Zool 2006; 84: 729-35.

[57] Pap PL, Szép T, Tökölyi J, Piper S. Habitat preference, escape behavior, and cues used by feather mites to avoid molting wing feathers. Behav Ecol 2005; 17: 277-84.

[58] McGraw KJ. Mechanics of melanin-based coloration. In: Hill GE, McGraw KJ, Eds. Mechanisms and Measurements. Cambridge: Harvard University Press; bird coloration 2006; vol. 1: pp. 243-94.

[59] Burtt EH. An analysis of physical, physiological, and optical aspects of avian coloration with emphasis on wood-warblers. Ornithol Monogr 1986; 38: 1-125.

[60] Bonser RHC. Melanin and the abrasion resistance of feathers Condor 1995; 97: 590-91.

[61] Kose M, Mand R, Møller AP. Sexual selection for white tail spots in the barn swallow in relation to habitat choice by feather lice. Anim Behav 1999; 58: 1201-05.

[62] Kose M, Møller AP. Sexual selection, feather breakage and parasites: the importance of white spots in the tail of the barn swallow (Hirundo rustica). Behav Ecol Sociobiol 1999; 45: 430-36.

[63] Price RD, Hellenthal RA, Palma RL, Johnson KP, Clayton DH. The chewing lice: world checklist and biological overview. Illinois Natural History Survey, Champaign, Illinois 2003.

[64] Vas Z, Csörg T, Moller AP, Rozsa L. The feather holes on the barn swallow Hirundo rustica and other small passerines are probably caused by Brueelia spp. lice. J Parasitol 2008; 94: 1438-40.

[65] Bush SE, Kim D, Lever J, Moyer BR, Clayton DH. Is melanin a defense against feather-feeding lice? Auk 2006; 123: 153-61.

[66] Goldstein G, Flory KR, Browne BA, Majid S, Ichida JM, Burtt EH, Jr. Bacterial degradation of black and white feathers. Auk 2004 121: 656-9.

[67] Gunderson AR, Frame AM, Swaddle JP, Forsyth MH. Resistance of melanized feathers to bacterial degradation: is it really so black and white? J Avian Biol 2008; 39: 539-45.

[68] Grande JM, Negro JJ, Torres MJ. The evolution of bird plumage colouration: a role for feather-degrading bacteria? Ardeola 2004 51: 375-83

[69] Zink RM, Remsen JV, Jr. Evolutionary processes and patterns of geographical variation in birds. Curr Ornithol 1986; 4: 1-69.

[70] Burtt EH, Ichida JM. Gloger's rule, feather-degrading bacteria, and color variation among song sparrows. Condor 2004; 106: 681-6.

[71] Cristol DA, Armstrong JL, Whitaker JM, Forsyth MH. Featherdegrading bacteria do not affect feathers on captive birds. Auk 2005; 122: 222-30.

[72] Clayton DH. Feather-busting bacteria. Auk 1999; 116: 302-4.

[73] Dumbacher JP, Pruett-Jones S. Avian chemical defense. Curr Ornithol 1996; 13: 137-74.

[74] Dumbacher JP, Beehler BM, Spande TF, Garraffo HM, Daly JW. Homobatrachotoxin in the Genus Pitohui: chemical defense in birds? Science 1992; 258: 799-801.

[75] Dumbacher JP, Spande TF, Daly JW. Batrachotoxin alkaloids from passerine birds: a second toxic bird genus (Ifrita kowaldi) from New Guinea. Proc Natl Acad Sci USA 2000; 97: 12970-5.

[76] Mouritsen KN, Madsen J. Toxic birds: defence against parasites? Oikos 1994; 69: 357-8

[77] Poulsen BO. Poison in Pitohui birds: against predators or ectoparasites? Emu 1994; 94: 128-9.

[78] Dumbacher JP. Evolution of toxicity in Pitohuis: I.effects of homobatrachotoxin on chewing lice (order Phthiraptera). Auk 1999; 116: 957-63.

[79] Pruett-Jones M, Pruett-Jones S. Analysis and ecological correlates of tick burdens in a New Guinea avifauna. In: Loye JE, Zuk M, Eds. Bird-parasite interactions: ecology, evolution, and behaviour. Oxford: Oxford University Press: UK 1991; pp. 154-76.

[80] Jones HL. Hematozoa from montane forest birds in Papua New Guinea. J Wild Dis 1985; 21: 7-10.

[81] Hagelin JC, Jones IL. Bird odors and other chemical substances: a defense mechanism or overlooked mode of intraspecific communication? Auk 2007; 124: 741-61.

[82] Jones IL. In: Poole A, Ed. Crested Auklet (Aethia cristatella). The birds of North America online. Ithaca: Cornell Lab of Ornithol 1993; doi: 10.2173/bna.70

[83] Douglas HD, III., Co JE, Jones TH, Conner WE. Heteropteran chemical repellents identified in the citrus odor of a seabird 
(crested auklet: Aethia cristatella): evolutionary convergence in chemical ecology. Naturwissenschaften 2001; 88: 330-2.

[84] Douglas HD, III., Co JE, Jones TH, Connor WE. Interspecific differeces in Aethia spp. auklet odorants and evidence for chemical defense against ectoparasites. J Chem Ecol 2004; 30: 1921-35.

[85] Douglas HD, III., Malenke JR, Clayton DH. Is the citrus-like plumage odorant of crested auklets (Aethia cristatella) a defense against lice? J Ornithol 2005; 146: 111-5.

[86] Douglas HD, III. Measurement of chemical emissions in crested auklets (Aethia cristatella). J Chem Ecol 2006; 32: 2559-67.

[87] Hagelin JC. The citrus-like scent of crested auklets: reviewing the evidence for an avian olfactory ornament. J Ornithol 2007; 148: S195-S201.

[88] Hagelin JC, Jones IL, Rasmussen LEL. A tangerine-scented social odor in a monogamous seabird. Proc Biol Sci 2003; 270: 1323-29.

[89] Douglas HD, III. In defense of chemical defense: quantification of volatile chemicals in feathers is challenging. Auk 2008; 125: 49697.

[90] Hagelin JC. New data and new questions for crested auklet research. Auk 2008; 125: 497-98.

[91] Douglas HD, III. Prenuptial perfume: alloanointing in the social rituals of the crested auklet (Aethia cristatella) and the transfer of arthropod deterrents. Naturwissenschaften 2008; 95: 45-53.

[92] Elder WH. The oil gland of birds. Wilson Bull 1954; 66: 6-31.

[93] Jacob J, Ziswiler V, The uropygial gland. In: Farner DS, King, JR, Parkes KC, Eds. Avian biology, New York: Academic Press 1982; Vol. 6: pp. 199-314.

[94] Moyer BR, Rock AN, Clayton DH. Experimental test of the importance of preen oil in rock doves (Columba livia). Auk 2003; 120: 490-6.

[95] Baxter M, Trotter MD. The effect of fatty materials extracted from keratins on the growth of fungi, with particular reference to the free fatty acid content. Sabouraudia 1969; 7: 199-206.

[96] Pugh GJF, Evans MD. Keratinophilic fungi associated with birds II. physiological studies. Trans Br Mycol Soc 1970; 54: 241-50.

[97] Bandyopadhyay A, Bhattacharyya SP. Influence of fowl uropygial gland and its secretory lipid components on growth of skin surface bacteria of fowl. Indian J Exp Biol 1996; 34: 48-52.

[98] Law-Brown J. Chemical defence in the Red-billed woodhoopoe, Phoeniculus purpureus, MSc thesis. University of Cape Town, South Africa 2001.

[99] Jacob J, Eigener U, Hoppe U. The structure of preen gland waxes from pelecaniform birds containing 3,7-dimethyloctan-1-ol -an active ingredient against dermatophytes. Z Naturforsch 1997; 52: 114-23.

[100] Bandyopadhyay A, Bhattacharyya SP. Influence of fowl uropygial gland and its secretory lipid components on growth of skin surface bacteria of fowl. Indian J Exp Biol 1999; 34: 48-52.

[101] Shawkey MD, Pillai SR, Hill GE. Chemical warfare? Effects of uropygial oil on feather-degrading bacteria. J Avian Biol 2003; 34: 345-49.

[102] Blanco G, Tella JL, Potti J, Baz A. Feather mites on birds: costs of parasitism or conditional outcomes? J Avian Biol 2001; 32: 271-74.

[103] Blanco G, Tella JL, Potti J. Feather mites on group-living redbilled choughs: a non-parasitic interaction? J Avian Biol 1997; 28: 197-206.

[104] Jovani R, Blanco G. Resemblance within flocks and individual differences in feather mite abundance on long-tailed tits, Aegithalos caudatus (L.). Ecoscience 2000; 7: 428-32.

[105] Clayton DH, Cotgreave P. Relationship of bill morphology to grooming behaviour in birds. Anim Behav 1994; 47: 195-201.

[106] Losito MP, Mirarchi RE, Baldassarre GA. Summertime activity budgets of hatching-year mourning doves. Auk 1990; 107:18-24.

[107] Goldstein DL. Estimates of daily energy expenditure in birds: the time-energy budget as an integrator of laboratory and field studies. Am Zool 1988; 28: 829-44.

[108] Croll DA, McLaren E. Diving metabolism and thermoregulation in common and thick-billed murres. J Comp Physiol [B] 1993; 163: 160-66.

[109] Ilienko AL. Peculiarities of the ecology of Passer domesticus L. affecting their infestation with Gamasid mites (In Russian). J Zool 1959; 38: 1060-68.

[110] Pomeroy DE. Birds with abnormal bills. Br Birds 1962; 55: 49-72.

[111] Ledger JA. Ectoparasite load in a Laughing Dove with a deformed mandible. Ostrich 1969; 41: 191-94.
[112] Clayton DH. Coevolution of avian grooming and ectoparasite avoidance. In: Loye JE, Zuk M, Eds. Bird-parasite interactions: ecology, evolution, and behaviour. Oxford: Oxford Univ Press 1991.

[113] Clayton DH, Lee PLM, Tompkins DM, Brodie ED. Reciprocal natural selection on host-parasite phenotypes. Am Nat 1999; 154: 261-70.

[114] Chandra RK, Newberne PM. Nutrition, immunity and infection. New York: Plenum Press 1977.

[115] Nelson WA. Effects of nutrition of animals on their ectoparasites. J Med Entomol 1984; 21:621-35.

[116] Gershwin ME, Beach RS, Hurley LS. Nutrition and immunity. Orlando, FL: Academic Press 1985.

[117] Cook ME. Nutrition and the immune response of the domesticated fowl. Crit Rev Poult Biol 1991; 3: 167-90.

[118] Kartman L. Preliminary observations on the relation of nutrition to pediculosis of rats and chickens. J Parasitol 1949; 35: 367-74.

[119] Nelson BC, Murray MD. The distribution of Mallophaga on the domestic pigeon (Columba livia). Int J Parasitol 1971; 1: 21-9.

[120] Brown NS. The effect of host beak condition on the size of Menacanthus stramineus populations of domestic chickens. Poult Sci 1972; 51: 162-4

[121] DeVaney JA. Effects of the chicken body louse, Menacanthus stramineus, on caged layers. Poult Sci 1976; 44: 430-5.

[122] Booth DT, Clayton DH, Block BA. Experimental demonstration of the energetic cost of parasitism in free-ranging hosts. Proc R Soc Lond B Biol Sci 1993; 253: 125-9.

[123] Clayton DH, Tompkins DM. Comparative effects of mites and lice on the reproductive success of rock doves (Columba livia). Parasitology 1995; 110: 195-206.

[124] Clayton DH, Walther BA. Influence of host ecology and morphology on the diversity of Neotropical bird lice. Oikos 2001; 94: 45567.

[125] Clayton DH, Moyer BR, Bush SE, et al. Adaptive significance of avian beak morphology for ectoparasite control. Proc R Soc Lond B Biol Sci 2005; 272: 811-17.

[126] Peterson AT. Adaptive geographical variation in bill shape of scrub jays (Aphelocoma coerulescens). Am Nat 1993; 142: 508-27.

[127] Bardwell E, Benkman CW, Gould WR. Adaptive geographic variation in Western scrub-jays. Ecology 2001; 82: 2617-27.

[128] Moyer BR, Peterson AT, Clayton DH. Influence of bill shape on ectoparasite load in Western Scrub-Jays. Condor 2002c; 104: 67578.

[129] Harrison CJO. Allopreening as agonistic behaviour. Behaviour 1965; 24: 161-209.

[130] Fraga RM. Bay-winged Cowbirds (Molothrus badius) remove ectoparasites from their brood parasites, the screaming cowbirds (M. rufoaxillaris). Biotropica 1984; 16: 223-26.

[131] Brooke ML. The effect of allopreening on tick burdens of molting eudyptid penguins. Auk 1985; 102: 893-5

[132] Murray MD. Influence of host behaviour on some ectoparasites of birds and mammals. In: Banard CJ, Behnke JM, Eds. Parasitism and Host Behaviour. New York: Taylor \& Francis 1990; pp. 290315.

[133] Wernham-Calladine CV. Guillemot preening activity in relation to tick infestation. Bull Brit Ecol Soc 1995; 26: 187-95.

[134] Radford AN, Du Plessis MA. Dual function of allopreening in the cooperatively breeding green woodhoopoe, Poeniculus purpueus. Behav Ecol Sociobiol 2006; 61: 221-30.

[135] Mooring MS. The effect of tick challenge on grooming rate by impala. Anim Behav 1995; 50: 377-92.

[136] Brewer TM. Wilson's American ornithology. New York: T. L. Magagnos and Company 1839.

[137] Brauner J. Observations on the behavior of a captive poor-will Condor 1953; 55: 68-74

[138] Clay T. The Mallophaga of birds. In: Baer JG, Ed. First symposium on host specificity among parasites of vertebrates. Neuchâtel, Inst. Zool Univ de Neuchâtel 1957; 120-55.

[139] Swainson W. Retrospective criticism: the pectinated claw of the goatsucker. Mag Nat Hist (London) 1831; 4: 275-6.

[140] Hayward J. Retrospective criticism: claw of the fern owl. Mag Nat Hist 1830; 3: 449.

[141] Meyer P. Nature guide to Carolina coast. Wilmington, NC: Avian Cetacean Press 1994

[142] Dillon B. On the Caprimulgus europaeus or fern owl, London. Mag Nat Hist 1830; 3: 30-3. 
[143] Sibley CG, Ahlquist JE. Phylogeny and classification of birds: a study in molecular evolution. New Haven: Yale Univ Press 1990.

[144] Austin OL. Birds of the world. New York: Golden Press 1961.

[145] Tyne JV, Berger AJ. Fundamentals of ornithology. New York: John Wiley \& Sons 1976.

[146] Terres JK. Encyclopedia of North American birds. New York: Alfred A. Knopf 1980.

[147] Walther BA, Cotgreave P, Price RD, Gregory RD, Clayton DH. Sampling effort and parasite species richness. Parasitol Today 1995; 11:306-10.

[148] Simmons KEL. Dusting. In: Campbell B, Lack E. Eds. A dictionary of birds. Vermillion, South Dakota: Buteo Books 1985; pp. 161-2.

[149] Hendricks P, Hendricks LN. Behavior and interaction of Bewick's and House wrens at a common dusting site, with comments on the utility of dusting. J Field Ornithol 1995; 66: 492-6.

[150] Xirouchakis S. Dust bathing in the bearded vulture (Gypaetus barbatus). J Raptor Res 1998; 32: 322.

[151] Healy WM, Thomas JW. Effects of dusting on plumage of Japanese Quail. Wilson Bull 1973; 85: 442-8.

[152] Borchelt PL, Duncan L. Dustbathing and feather lipid in bobwhite (Colinus virginianus). Condor 1974; 76: 471-2.

[153] van Liere DW. The significance of fowl's bathing in dust. Anim Welf 1992; 1: 187-202.

[154] Hoyle WL. Transmission of poultry parasites by birds with special reference to the "English" or house sparrow and chickens. Trans Kans Acad Sci 1938; 41: 379-84

[155] Kilham L. Dirt-bathing by a pileated woodpecker. Bird Banding 1975; 46: 251-2

[156] Wigglesworth VB. Action of inert dusts on insects. Nature 1944; 153: 493-4.

[157] Edwards JS, Schwartz LM. Mount St. Helens ash: a natural insecticide. J Field Ornithol 1981; 66: 492-6.

[158] Borchelt PL. The organization of dustbathing components in bobwhite quail (Colinus virginianus). Behaviour 1975; 53: 217-37.

[159] Bliss B, Heppner FH. Effects of molting on dustbathing in Japanese quail (Coturnix coturnix japonica). Condor 1977; 79: 395-6.

[160] Vestergaard K, Hogan JA. The development of a behavior system: Dustbathing in the Burmese red junglefowl. III. Effects of experience on stimulus preference. Behaviour 1992; 121: 215-30.

[161] Petherick JC, Seawright E, Waddington D, Duncan IJH, Murphy LB. The role of perception in the causation of dustbathing behaviour in domestic fowl. Anim Behav 1995; 49: 1521-30.

[162] Simmons KEL. The sunning behaviour of birds, $1^{\text {st }}$ ed. Bristol: Bristol Ornithological Club 1986.

[163] Moyer BR, Wagenbach GE. Sunning by Black Noddies (Anous minutus) may kill chewing lice (Quadraceps hopkinsi). Auk 1995; 112: 1073-7.

[164] Kluger KJ. Fever: its biology, evolution, and function. Princeton: Princeton University Press 1979.

[165] Kluger MJ, Kozak W, Conn CA, Leon LR, Soszynski D. The adaptive value of fever. In: Mackowiak PA, Ed. Fever: basic mechanisms and management. $2^{\text {nd }}$ ed. Philadelphia: Lippincott-Raven 1997; pp. 255-66.

[166] Mackowiak PA, Ed. Philadelphia, Fever: basic mechanisms and management, $2^{\text {nd }}$ ed. Philadelphia: Lippincott-Raven 1997.

[167] Kluger MJ, Ringler DH, Anver MR. Fever and survival. Science 1975; 188: 166-8

[168] Covert JB, Reynolds WW. Survival value of fever in fish. Nature 1977; 267: 43-5.

[169] Hauser DC. Some observations on sun-bathing in birds. Wilson Bull 1957; 69: 78-90

[170] Cullen, JM, Ashmole NP. The black noddy Anous tenuirostris on ascension island. part 2. Behaviour. Ibis 1963; 103b: 423-46.

[171] Cade TJ. Sun-bathing as a thermoregulatory aid in birds. Condor 1973; 75: 106-33.

[172] Blem CR, Blem LB. Do swallows sunbathe to control ectoparasites? An experimental test. Condor 1993; 95: 728-30.

[173] Barlow JC, Klaas EE, Lenz JL. Sunning of bank swallows and cliff swallows. Condor 1963; 65: 438-40.

[174] Blem CR, Blem LB. Some observations of sunbathing in swallows. J Field Ornithol 1992; 63: 53-6.

[175] Blem CR, Blem LB. Effects of some meteorological variables on basking behavior in violet-green swallows. J Field Ornithol 2000; 71: 339-44.

[176] Ali S. Do birds employ ants to rid themselves of ectoparasites? J Bombay Nat Hist Soc 1936; 38: 628-31.
[177] Eichler W. Der biologie der federlinge. J Ornithol 1936; 84: 471 505.

[178] Whitaker LM. A résumé of anting, with particular reference to a captive Orchard Oriole. Wilson Bull 1957; 69: 195-262.

[179] Kelso L, Nice MM. A Russian contribution to anting and feather mites. Wilson Bull 1963; 75: 23-6.

[180] Simmons KEL. Anting and the problem of self-stimulation. J Zool 1966; 149: 145-62.

[181] Clayton DH, Wolfe ND. The adaptive significance of selfmedication. Trends Ecol Evol 1993; 8: 60-3.

[182] Simmons KEL. Anting. In: Campbell B, Lack E, Eds. A dictionary of birds. Vermillion: South Dakota, Buteo Books 1985; p. 19.

[183] Dubinin VB. Feather mites (Analgesoidea). Part I. Introduction to their study. Fauna USSR Paukoobraznye 1951; 6: 1-363.

[184] Bennett ATD, Lloyd MH, Cuthill IC. Ant-derived formic acid can be toxic for birds. Chemoecology 1996; 7: 189-90.

[185] Ehrlich PR, Dobkin DS, Wheye D. The adaptive significance of anting. Auk 1986; 103: 835.

[186] Revis HC, Waller DA. Bactericidal and fungicidal activity of ant chemicals on feather parasites: an evaluation of anting behavior as a method of self-medication in songbirds. Auk 2004; 121(4): 12628 .

[187] Clunie F. Jungle Mynah "anting" with a millepede. Notornis 1976; 23: 77 .

[188] Eyles F. Robins and millepedes. Birds RSPB Mag 1983; 9: 67.

[189] Wenny D. Three-striped Warbler (Basileuterus tristriatus) "anting" with a Caterpillar. Wilson Bull 1998; 110: 128-31.

[190] Vander Werf EA. 'Elepaio "anting" with a garlic snail and a schinus fruit. J Field Ornithol 2005; 76(2): 134-37.

[191] Eisner T, Eisner M, Aneshansley D. Pre-ingestive treatment of bombardier beetles by jays: food preparation by "anting" and "sand-wiping." Chemoecology 2005; 15: 227-33.

[192] Robinson HN. The grackle and the green grape. Indiana Audubon Soc. Year Book 1945; vol. 23: p.14.

[193] Laskey AR. Bronzed grackle anointing plumage with orange-skin. Wilson Bull 1948; 60: 244-5.

[194] Clayton DH, Vernon JG. Common grackles anting with lime fruit and its effect on ectoparasites. Auk 1993: 110: 951-2.

[195] Groff ME, Brackbill H. Purple grackles "anting" with walnut juice. Auk 1946; 63: 246-7.

[196] Nero RW, Hatch DRM. Common grackles anting with marigold flowers. Blue Jay 1984; 42: 212-14.

[197] Dennis JV. Commentary on grackles anting with marigold blossoms. Blue Jay 1985; 43: 175-7.

[198] Nero RW. Common grackles anting with "weed and feed" lawn chemicals. Blue Jay 1996; 54: 31-4.

[199] Hill RH. Bronzed grackle "anting" with mothballs. Wilson Bull 1946; 58: 112

[200] DuBois CA. Grackle anting with a mothball. Auk 1969; 86: 131.

[201] Clark CC, Clark L, Clark L. "Anting" behavior by common grackles and European starlings. Wilson Bull 1990; 102: 167-9.

[202] Delhey K, Peters A, Kempenaers B. Cosmetic coloration in birds: occurrence, function and evolution. Am Nat 2007; 169: S145-58.

[203] Frey H, Roth-Callies N. Zur genese der haftfarbe (rostfarbung durch eisenoxid) beim bartgeier, Gypaetus barbatus. Egretta 1994; 37: $1-22$

[204] Negro JJ, Margalida A, Hiraldo F, Heredia R. The function of the cosmetic coloration of bearded vultures: when art imitates life. Anim Behav 1999; 58: F14-7.

[205] Arlettaz R, Christe P, Surai PF, Møller AP. Deliberate rusty staining of plumage in the bearded vulture: does function precede art? Anim Behav 2002; 64: F1-3.

[206] Wingfield JC, Ishii S, Kikuchi M, et al. Biology of a critically endangered species, the Toki (Japanese crested ibis) Nipponia nippon. Ibis $2000 ; 142: 1-11$.

[207] Brown LH, Urban EK, Newman K. The birds of Africa. London Academic Press 1982.

[208] Landsdown RV. Some calls, displays and associated morphology of the cinnamon bittern (Ixobrychus cinnamomeus) and their possible functions. Colonial Waterbirds 1988; 11: 308-10.

[209] Fessl B, Kleindorfer S, Tebbich S. An experimental study on the effects of an introduced parasite in Darwin's finches. Biol Conserv 2006; 127: 55-61.

[210] Poulin R. Evolutionary ecology of parasites. Princeton: Princeton University Press 2007. 
[211] Møller AP, Dufa R, Allander K. Parasites and the evolution of host social behavior. Adv Study Behav 1993; 22: 65-102.

[212] Brown CR, Brown MB. Ectoparasites as a cost of coloniality in cliff swallows (Hirundo pyrrhonota). Ecology 1986; 67: 1206-18.

[213] Christe P, Oppliger A, Richner H. Ectoparasite affects choice and use of roost sites in the great tit, Parus major. Anim Behav 1994; 47: 895-8.

[214] Oppliger A, Richner H, Christe P. Effect of an ectoparasite on lay date, nest-site choice, desertion, and hatching success in the great Tit (Parus major). Behav Ecol 1994; 5: 130-4.

[215] Merino S, Potti J. Mites and blowflies decrease growth and survival in nestling pied flycatchers. Oikos 1995; 73: 95-103.

[216] Merino S, Potti J. Pied flycatchers prefer to nest in clean nest boxes in an area with detrimental nest ectoparasites. Condor 1995b; 97: 828-31.

[217] Merilä J, Allandar K. Do great tits prefer ectoparasite-free roost sites? An experiment. Ethology 1995; 99: 53-60.

[218] Loye JE, Carroll SP. Ectoparasite behavior and its effects on avian nest site selection. Ann Entomol Soc Am 1998; 91: 159-63.

[219] Rytkonen S, Lehtonen R, Orell M. Breeding great tits (Parus Major) avoid nestboxes infested with fleas. Ibis 1998; 140: 687-90.

[220] Thompson CF. Ectoparasite behavior and its effects on avian nestsite selection: corrections and comment. Ann Entomol Soc Am 1999; 92: 108-9.

[221] Rohner C, Krebs CJ, Hunter DB, Currie DC. Roost site selection of great horned owls in relation to black fly activity: An anti-parasite behavior? Condor 2000; 102: 950-5.

[222] Richner H. Host-parasite interactions and life-history evolution. Zoology 1998; 101: 333-44.

[223] Humphries DA. The host-finding behaviour of the hen flea, Ceratophyllus gallinae (Schrank) (Siphonaptera). Parasitology 1968; 58: 403-14.

[224] Christe P, Richner H, Oppliger A. Of great tits and fleas: sleep baby sleep. Anim Behav 1996; 52: 1087-92.

[225] Hurtrez-Bousses S, Renaud F, Blondel JP, Galan M. Effects of ectoparasites of young on parents' behaviour in a mediterranean population of blue tits. J Avian Biol 2000; 31: 266-9.

[226] Tripet F, Glaser M, Richner H. Behavioural responses to ectoparasites: time-budget adjustments and what matters to blue tits Parus caeruleus infested by fleas. Ibis 2002; 144: 461-9.

[227] Pacejka AJ, Santana E, Harper RG, Thompson CF. House Wrens Troglodytes aedon and nest-dwelling ectoparasites: mite population growth and feeding patterns. J Avian Biol 1996; 27: 273-8.

[228] Lozano GA. Parasitic stress and self-medication in wild animals. Adv Study Behav 1998; 27: 291-317.

[229] Clark L, Mason JR. Use of nest material as insecticidal and antipathogenic agents by the European starling. Oecologia 1985; 67: $169-76$.

[230] Clark L, Mason JR. Effect of biologically active plants used as nest material and the derived benefit to starling nestlings. Oecologia 1988; 77: 174-80.

[231] Ontiveros D, Caro J, Pleguezuelos JM. Green plant material versus ectoparasites in nests of bonelli's eagle. J Zool 2008; 274: 99-104.
[232] Shutler D, Campbell AA. Experimental addition of greenery reduces flea loads in nests of a non-greenery using species, the tree swallow Tachycineta bicolor. J Avian Biol 2007; 38:7-12.

[233] Gwinner H, Oltrogge M, Trost L, Nienaber U. Green plants in starling nests: effects on nestlings. Anim Behav 2000; 59: 301-9.

[234] Mennerat A, Perret P, Bourgault P, et al. Aromatic plants in nests of blue tits: positive effects on nestlings. Anim Behav 2009; 77: 569-74

[235] Smith NG. The advantage of being parasitized. Nature 1968; 219: 690-4.

[236] Gehlbach FR, Baldridge RS. Live blind snakes (Leptotyphlops dulcis) in eastern screech owl (Otus asio) nests: a novel commensalism. Oecologia 1987; 71: 560-3.

[237] Bowman RI, Billeb SI. Blood-eating in a Galapagos finch. Living Bird 1965; 4: 29-44

[238] Foster WA. Total brood mortality in late-nesting Cliff Swallows. Condor 1968; 70: 275

[239] Moss WW, Camin JH. Nest parasitism, productivity and clutch size in purple martins. Science 1970; 168: 1000-3.

[240] King KA, Blankinship DR, Paul RT. Ticks as a factor in the 1975 nesting failure of Texas brown pelicans. Wilson Bull 1977a; 89: 157-8.

[241] King KA, Keith JO, Mitchell CA, Keirans JE. Ticks as a factor in nest desertion of California brown pelicans. Condor 1977b; 79: 507-9.

[242] Duffy DC. The ecology of tick parasitism on densely nesting peruvian seabirds. Ecology 1983; 64: 110-9.

[243] Emlen JT. Responses of breeding cliff swallows to nidicolous parasite infestations. Condor 1986; 88: 110-1.

[244] Chapman BR, George JE. The effects of ectoparasites on cliff swallow growth and survival. In: Loye JE, Zuk M, Eds. Birdparasite interactions: ecology, evolution, and behaviour. Oxford: Oxford University Press 1991

[245] Richner H, Oppliger A, Christe P. Effect of an ectoparasite on reproduction in great tits. J Anim Ecol 1993; 62: 703-10.

[246] Cotgreave P, Clayton DH. Comparative analysis of time spent grooming by birds in relation to parasite load. Behaviour 1994; 131: 171-87.

[247] Brown NS, Wilson GI. A comparison of the ectoparasites of the house sparrow (Passer domesticus) from North America and Europe. Am Midl Nat 1975; 94: 154-65.

[248] Grant PR. Ecology and Evolution of Darwin's Finches. Princeton: Princeton University Press 1986

[249] Smith TB. Bill size polymorphism and intraspecific niche utilization in an African finch. Nature 1987; 329: 717-19.

[250] Benkman CW. Adaptation to single resources and the evolution of crossbill (Loxia) diversity. Ecol Monogr 1993; 63: 305-25.

[251] Redpath S. Vigilance levels in preening dunlin (Caladris alpina). Ibis 1988; 130: 555-7.

[252] Sibley CG, Monroe BL. Distribution and taxonomy of birds of the world. New Haven: Yale University Press 1990.

This is an open access article licensed under the terms of the Creative Commons Attribution Non-Commercial License (http://creativecommons.org/licenses/ by-nc/3.0/) which permits unrestricted, non-commercial use, distribution and reproduction in any medium, provided the work is properly cited. 